\title{
33. COMPOSITION OF SEDIMENTS OF THE JAPAN TRENCH TRANSECT, LEGS 56 AND 57, DEEP SEA DRILLING PROJECT
}

\author{
Ulrich Mann and German Müller, Institut für Sedimentforschung, Universität Heidelberg, Heidelberg, Germany
}

\begin{abstract}
Altogether 513 samples from sediments of Cretaceous to Pleistocene age from DSDP Legs 56 and 57 were examined by x-ray methods. The main constituents are clay minerals, quartz, feldspar, opaline silica, and volcanic glass.

The sediment composition reflects the position of the sites in relation to the main source area, the Japanese Island Arc. For example, relatively coarse-grained material rich in quartz and feldspar was deposited closest to the islands, whereas finer-grained material rich in clay minerals (mainly smectite and illite, with lesser amounts of kaolinite and chlorite) was deposited farther seaward.

Vertical fluctuations in the composition of the sediments show the same trend in all sites and are caused mainly by a fluctuating contribution of biogenic silica with time.

A trend reversal in the chlorite/kaolinite ratio at Site 438 supports the conclusion that the subsidence of the Oyashio ancient landmass took place during the middle Miocene. That ratio also indicates a northwest drift in the position of Site 436 by sea floor spreading. Oscillations of the illite/smectite ratio during the Pleistocene at Site 436 show the variations of climate during this period.

During early diagenesis potassium is fixed in smectite. With increasing depth of burial a smectite-illite mixed layer is formed, with increasing illite layering. At Sites 434, 440, and 441, stepwise changes confirm intensive tectonic process at the midslope terrace and the lower inner slope of the Japan Trench.
\end{abstract}

\section{INTRODUCTION}

The Japan Trench transect is the first IPOD transect across an active margin and was designed to study the effects of plate convergence of continental and island arc margins. Altogether seven sites were drilled across the transect (Figures 1 and 2), six of which were on the inner trench slope and one on the outer rise.

All sites on the inner trench slope penetrated hemipelagic sediments of Pleistocene and Tertiary age. Only at Site 439 and on the outer rise at Site 436 were a few meters of older (Cretaceous) sediments-silicified claystone, pelagic clays, and chert- recovered.

\section{DRILLING}

Details on individual holes are reported in the site chapters, Part 1 of this volume. We give a brief summary of the major sedimentological findings.

\section{Site 434, Holes 434, 434A, and 434B}

This site was drilled on a small terrace in the middle of the inner trench slope at a water depth of $5985 \mathrm{me}-$ ters, closest to the floor of the trench axis. It was continuously cored to a depth of 637.5 meters. Core recovery was very poor because of the highly fractured nature of the sediments. The presence of fracturing and repeated biostratigraphic zones due to mineralogical repetition is consistent with the view that these sediments are part of an accretion prism induced by subduction of the Pacific Plate. In general, the lithology is very uniform and consists mainly of hemipelagic diatomaceous clays and claystones with varying amounts of vitric ash.

\section{Site $\mathbf{4 3 5}$, Holes 435 and $\mathbf{4 3 5} \mathrm{A}$}

The site was drilled on the upper slope of the landward wall of the Japan Trench at a water depth of 3401 meters. It was continuously cored to a depth of 244.5 meters and penetrated a very uniform sequence of sediments composed of hemipelagic diatomaceous silty clay (Pleistocene) and muddy diatomaceous ooze (Pliocene).

\section{Site 436}

A continuous series of cores was recovered on the outer rise of the Japan Trench at a water depth of 5240 meters. Penetration depth was 397.5 meters. We recognized three major lithologic units: I vitric diatomaceous silty clay and claystone (hemipelagic); II radiolarian diatomaceous claystone (transition pelagic - hemipelagic); and III pelagic clay and chert (pelagic).

\section{Site 438, Holes 438, 438A, and 438B}

Three holes, the deepest cored to 1040.7 meters, were drilled at water depths of 1547.5 to 1564.5 meters on the landward side of the trench in the fore-arc basin. We 


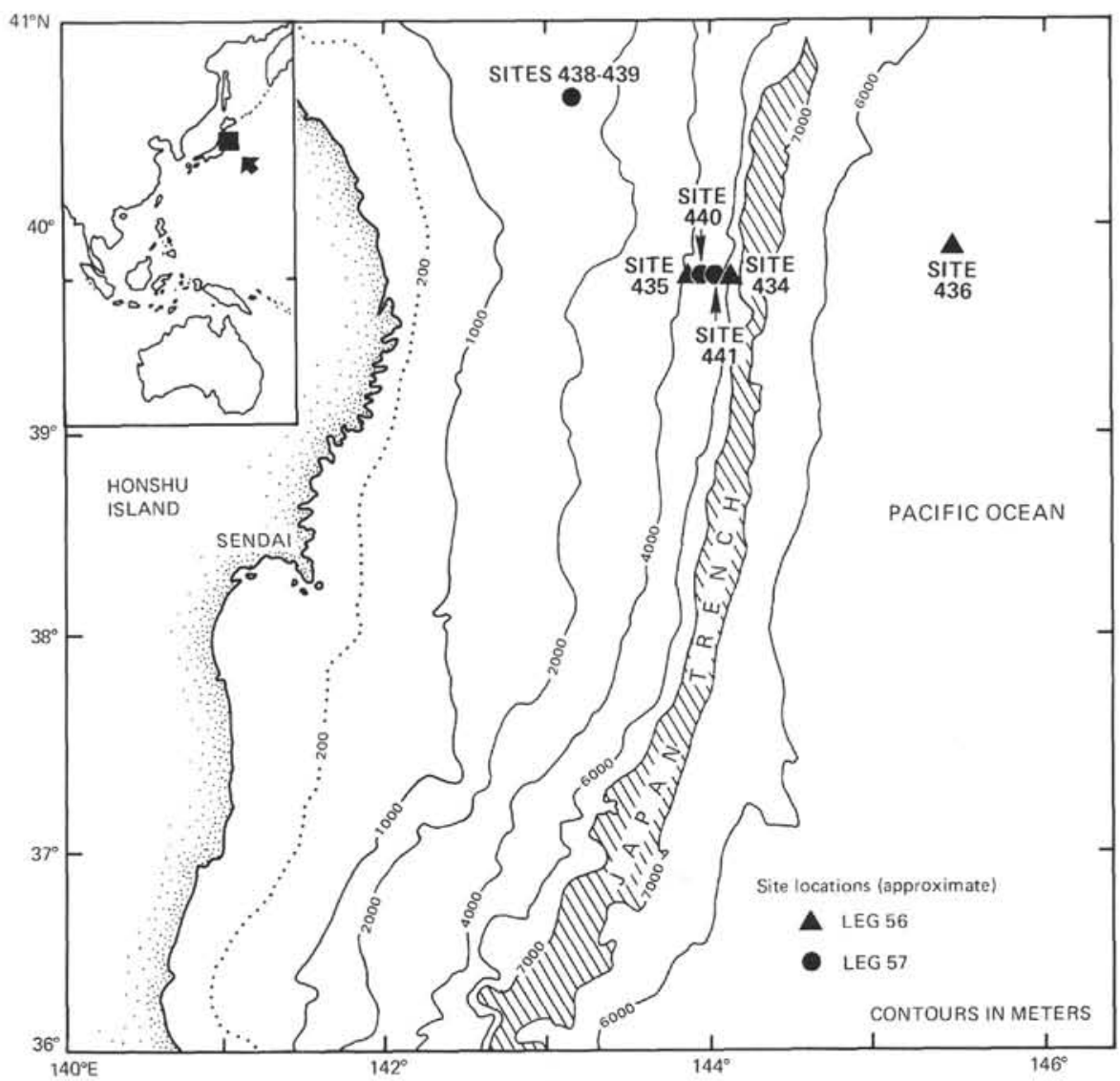

Figure 1. Drilling sites, Legs 56 and 57 (modified after von Huene and Nasu, 1978).

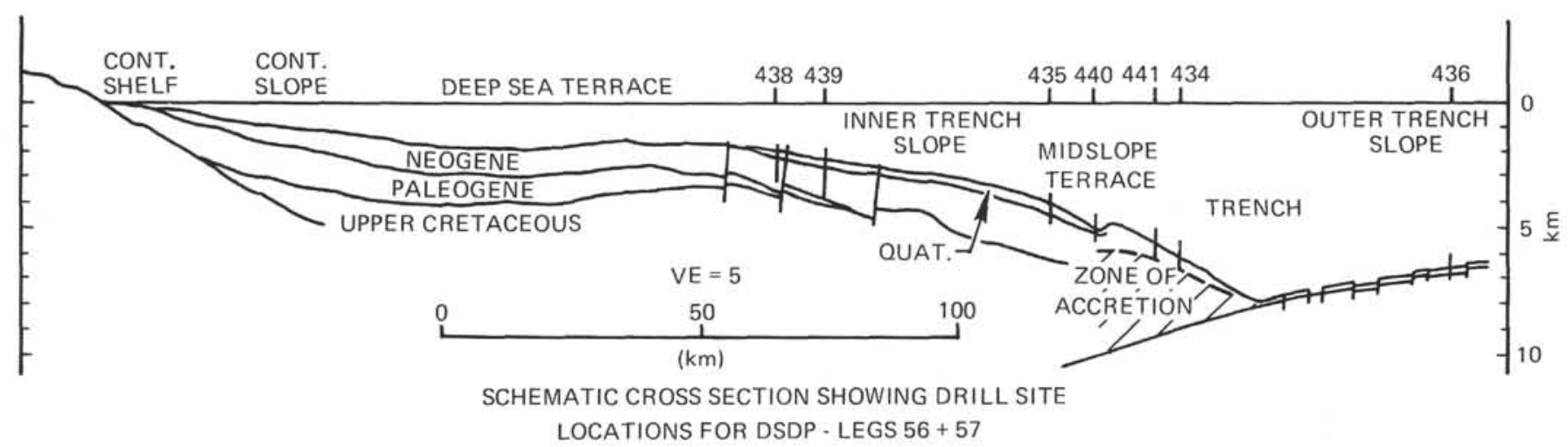

Figure 2. Schematic cross section of the drilling sites, Legs 56 and 57 (von Huene and Nasu, 1978).

distinguished four major lithological units: I diatomaceous sandy silty clay; IIA diatomaceous clay; IIB diatomaceous claystone; IIC diatomaceous claystone and limestone beds; III diatomaceous vitric claystone; and IV clayey siltstone.

\section{Site 439}

At this site, close to Site 438 , we cored the deeper continuation of the sediments encountered at Site 438 . Below a depth of 849.5 meters we recovered a continuous series of cores. The major lithologic units are III vitric claystone; IV silty claystone; V sandstone and siltstone; VI conglomerate and breccia; and VII silicified claystone.
Site 440, Holes 440, 440A, and 440B

Three holes were drilled at a water depth of 4509 meters on the Japan Trench landward slope in the vicinity of Sites 434,435 , and 441 . Altogether 814.0 meters were continuously cored. Two major lithological units were differentiated: I diatomaceous sandy silty clay; IIA diatomaceous clay; and IIB claystone and diatomaceous claystone.

\section{Site 441, Holes 441, 441A, and 441B}

The site was drilled close to Site 434 at a water depth of 5650 meters and penetrated 687.0 meters of sediments, of which we recovered only about 14 per cent. 


\section{METHODS}

Altogether 513 samples were investigated by $\mathrm{x}$-ray methods. The samples were dried at $70^{\circ} \mathrm{C}$, powdered, and $\mathrm{x}$-rayed under the following conditions: $\mathrm{CuK}_{\alpha}$ radiation, Ni filter, $38 \mathrm{kV} / 24 \mathrm{~mA}$, range cps $1 \times 10^{3}$, time constant $1,1^{\circ}$ beam slit, $0.1-\mathrm{mm}$ receiving slit, $1^{\circ}$ antiscattering slit.

Goniometric speed was $1^{\circ} 2 \theta / \mathrm{min}$, paper speed 10 $\mathrm{mm} / \mathrm{min}$. All samples were $\mathrm{x}$-rayed from $3^{\circ}$ to $40^{\circ} 2 \Theta$. In all x-ray determinations of the bulk samples, the omnipresent halite peak at $2.82 \AA$ was used for optimal calibration.

For the recognition and determination of the properties of the different clay mineral groups, the $<2-\mu \mathrm{m}$ fraction was separated from the bulk sample by sedimentation analysis after desalination and ultrasonic disintegration. The residue clay fraction, mixed to homogenous paste in order to obtain an optimal texture, was then smeared on a glass slide. All smear slides were then $x$-rayed under the same conditions as the bulk samples-i.e., between $2^{\circ}$ and $27^{\circ} 2 \Theta$ (1) untreated, (2) glycolated, and, when necessary, (3) heated.

Since the sediments recovered in Legs 56 and 57 are high in two amorphous constituents, biogenic silica and volcanic glass, the "normal" procedure of semiquantitative x-ray analysis applied in previous Legs (Mann and Müller, in press, and 1980) could not be applied without modifications. For these studies, the flow scheme of Table 1 was applied.

\section{Amorphous Constituents}

Numerous attempts have been made quantitively to determine biogenic silica in sediments by (1) x-ray methods (Goldberg, 1958; Calvert, 1966): the sample is heated to $1000^{\circ} \mathrm{C}$ for 4 hours, during which opal-A crystallizes into cristobalite, the intensities of which are evaluated; (2) preferential dissolution of opal with alkaline solutions; (3) normative calculation by subtracting nonbiogenic silica, calculated from the $\mathrm{Al}$ and $\mathrm{Mg}$ concentrations in the sediment, from the total silica content of the sample (Leinen, 1977).

None of these methods could be applied in the present study for the following reasons: (1) Volcanic glass partially crystallizes into cristobalite. (2) Volcanic glass

TABLE 1

Flow Scheme of Semiquantitative Analyses of Bulk Composition of Sediments from Legs 56 and 57

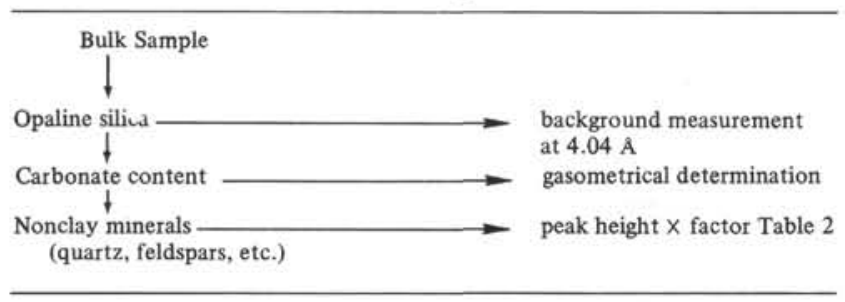

Remainder $=$ clay minerals plus amorphous constituents is partially leached by alkaline solutions. (3) Method (3) was originally developed for pelagic sediments and is not applicable to sediments containing large amounts of terrigenous constituents, as is the case for the hemipelagic deposits of Legs 56 and 57.

Another method, the infrared determination of opal in siliceous deep sea sediments (Chester and Elderfield, 1968 ), is very time-consuming and requires elaborate apparatus (a double-beam recording spectrophotometer) if, as is the case in all our samples, quartz is present.

In order to solve this problem, we applied an x-ray method which measures the height of a broad, diffuse reflection band of opal extending from about $15^{\circ}$ to $32^{\circ}$ $2 \Theta$ and has its maximum at about $22^{\circ} 2 \Theta(4.04 \AA)$.

Figure 3 depicts the $\mathrm{x}$-ray diffractograms of two different opaline sponge spicules (Geodia) and of opal from an opal mine in Australia (Bulla Creek, Queensland). For the purpose of comparison, the diffractogram of a volcanic glass (Monte Somma, Vesuvio, Naples) is depicted. The volcanic glass also exhibits a broad reflection band, which, however, is much less intensive, more elongated, and has no pronounced maximum. It is therefore not possible to estimate the amounts of volcanic glass from the background measurements. On the other hand, the error arising from an admixture of volcanic glass to biogenic opal is relatively small and does not greatly influence the estimate of the opal concentration. There is no doubt that the concentration of opal is somewhat overestimated by this method if volcanic glass (or other amorphous constituents) is present. Figure 4 shows the diffractograms of an artificial sediment composed of 40 per cent illite, 40 per cent smectite, and 20 per cent quartz plus feldspar which was mixed with progressively increasing amounts of sponge spicules.

The development of the opal band at the expense of the other minerals can be clearly seen. The calibration curve of Figure 5 was constructed from the diagrams in Figure 4.

\section{Carbonates}

Total carbonate content was determined gasometrically with a carbonate bomb (Müller and Gastner, 1971). Carbonate content less than 3 per cent, which cannot be accurately determined by this method, is not indicated in the "Carbonates" column of Tables 4 through 10 . The carbonate species (calcite and rhodochrosite) were determined by x-ray methods.

\section{Quartz, Feldspar, and Other Nonclay Minerals}

The strongest peaks of all minerals present (with the exception of the clay minerals) were used to calculate their concentrations by multiplying the peak intensity with a factor derived from defined artificial mixtures of the different minerals (Table 2).

\section{Clay Minerals}

According to our experience, the (020) peak of the clay minerals is not adequate for an accurate estimate of the amount of clay minerals in all cases in which amorphous materials are present. The amorphous constitu- 







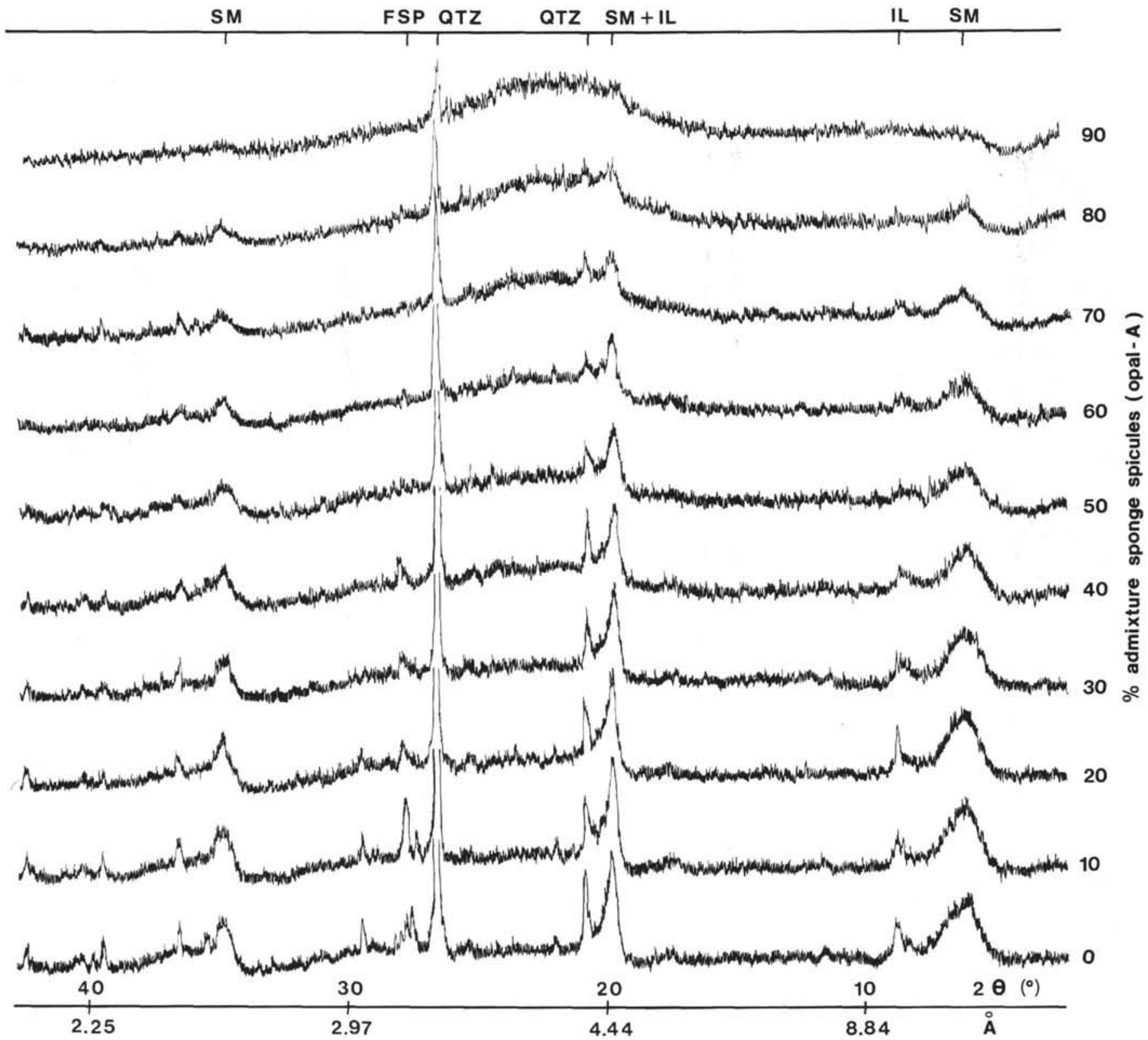

Figure 4. X-ray diffractograms of an artificial sediment (40 per cent illite, 40 per cent smectite, 20 per cent quartz plus feldspar) mixed with progressively increasing amounts of sponge spicules.

ents influence the $(020)$ peak in such a way that its base line cannot be exactly traced. The peak area of the (020) peak is further affected if the relative amounts of the different groups of clay minerals which participate in the composition of a sample vary greatly among samples.

In the present study it was therefore not possible to quantify the percentage of clay minerals by direct peak measurements. The only way to do so is to subtract all other constituents that can be determined by $\mathrm{x}$-ray methods-i.e., the crystalline materials and-with certain restrictions-opaline silica. It must be emphasized that the margin of error of this method is all the larger the greater the amount of amorphous constituents, especially when volcanic glass is "added" to the clay minerals.
The relative abundance of different clay mineral groups was calculated from the (001) peak areas of the glycolated clay minerals, using the multiplying factors given in Table 3 (Biscaye, 1965). The (001) kaolinite + (002) chlorite peaks which appear at about the same position, $7.19 \AA$, were "dissolved" for the two clay mineral groups by separating the (002) kaolinite from the (004) chlorite peak with a goniometric speed of $1 / 8^{\circ} 2 \theta$ per minute: kaolinite $=3.58 \AA$ peak area $/ 3.58 \AA+3.54$ $\AA$ peak areas.

\section{RESULTS}

The results of our investigations are listed in Tables 4 through 10 and graphically represented in Figures 6 through 11. (Symbols and abbreviations indicate the following: $\operatorname{tr}=$ trace, $p=$ plagioclase,$k=$ potassium feldspars, 




Figure 5. Calibration curve of opal-A drawn up from the diagrams of Figure 4.

TABLE 2

Factor Table for Minerals under Investigation Bulk Mineralogy

\begin{tabular}{lccc}
\hline \multicolumn{1}{c}{ Mineral } & $\begin{array}{c}\text { Peak } \\
2 \Theta\left({ }^{\circ}\right)\end{array}$ & $d(\AA)$ & Factor \\
\hline Quartz & 26.7 & 3.34 & 1.3 \\
Feldspar & $27.4-28.0$ & $3.25-3.18$ & 2.0 \\
Pyroxene & 29.9 & 2.99 & 2.0 \\
Hornblende & 10.5 & 8.42 & 2.0 \\
Opal-CT & $21.5-21.9$ & $4.15-4.05$ & 1.5 \\
Clinoptilolite & 9.8 & 8.99 & 2.0 \\
Pyrite & 33.0 & 2.71 & 2.0 \\
Gypsum & 11.7 & 7.56 & 2.0 \\
Rhodochrosite & 31.4 & 2.85 & 2.0 \\
Apatite & 32.2 & 2.78 & 2.0 \\
Analcite & 26.0 & 3.42 & 2.0 \\
\hline
\end{tabular}

$+=$ smectite/illite mixed layers, and pal $=$ palygorskite. $)$ The following constituents as traced by $\mathrm{x}$-ray analysis (in decreasing order of magnitude) make up the sediments of Legs 56 and 57: (1) clay minerals (smectite, illite, chlorite, kaolinite, smectite-illite mixed layer minerals, palygorskite); (2) opal-A (diatoms, radiolarians, sponge spicules, silicoflagellates); (3) quartz and feldspars; (4) volcanic glass; (5) pyrite, pyroxene, hornblende, carbonates (cal-
TABLE 3

Factor Table for Minerals under Investigation Clay Mineralogy

\begin{tabular}{lrrc}
\hline \multicolumn{1}{c}{ Mineral } & $\begin{array}{c}\text { Peak } \\
2 \Theta\left({ }^{\circ}\right)\end{array}$ & $d(\AA)$ & Factor \\
\hline Smectite & 5.2 & 17.0 & 1 \\
Chlorite & 12.3 & 7.2 & 2 \\
Illite & 8.8 & 10.0 & 4 \\
Kaolinite & 12.3 & 7.2 & 2 \\
Palygorskite & 8.4 & 10.5 & 1 \\
\hline
\end{tabular}

cite, rhodochrosite, siderite); (6) clinoptilolite, opal-CT; and (7) mica, apatite, analcime.

Site 434, Holes 434, 434A, and 434B (Table 4, Figure 6)

Of all the sites investigated, Site 434 shows the least variation in sediment composition with depth. Clay minerals (+volcanic glass) make up from 48 to 84 per cent of the sediment. Smectite and illite, in about equal proportions, make up 80 per cent of the clay fraction, and the remainder is chlorite and lesser kaolinite. Palygorskite is present in traces in the middle section of the site. Opal-A ranges between trace amounts and 40 per cent, with an average concentration of 15 per cent. Quartz and feldspar are present in quantities between 10 and 25 per cent, and the quartz/feldspar ratio averages 3.1. Pyroxene, hornblende, and pyrite occur in trace quantities; carbonates are enriched in five samples. Lithological Sub-unit IIB (tuffite) cannot be verified by mineralogical studies. One explanation for this lies in the impossibility of separating volcanic glass from clay minerals by $\mathrm{x}$-ray methods alone.

In Figure 12 results of measurements of the "sharpness" (ratio peak height/width at mid-height) of the (001) peak of glycolated smectite are presented. The vertical distribution of the sharpness shows a general tendency to decrease stepwise with depth.

\section{Site 435, Holes 435 and $\mathbf{4 3 5 A}$ (Table 5, Figure 7)}

The vertical distribution of the different constituents shows a clear bipartition which coincides with the two different lithological sub-units:

Unit IA (Pleistocene) is very low in opal-A (average 3.5 per cent) and rich in clay minerals plus volcanic glass (average 74.5 per cent) and quartz plus feldspars (average 19.8 per cent). The quartz/feldspar ratio averages 2.1. The concentration of heavy minerals is relatively high.

Unit IB, composed of sediments of Pliocene age, has much higher opal-A contents (average 26.4 per cent) but lower concentrations of clay minerals plus volcanic glass (average 58.4 per cent) and quartz plus feldspars (average 12.1 per cent). The quartz/feldspar ratio averages 3.0. The heavy mineral concentration is relatively low. Opal-A shows a general tendency to increase with depth at the expense of clay minerals and volcanic glass. Carbonate concentrations up to 9 per cent occur in altogether 21 samples. The clay mineral composition shows no significant variation with depth. 
TABLE 4

Bulk Composition and Clay Mineralogy, Site 434

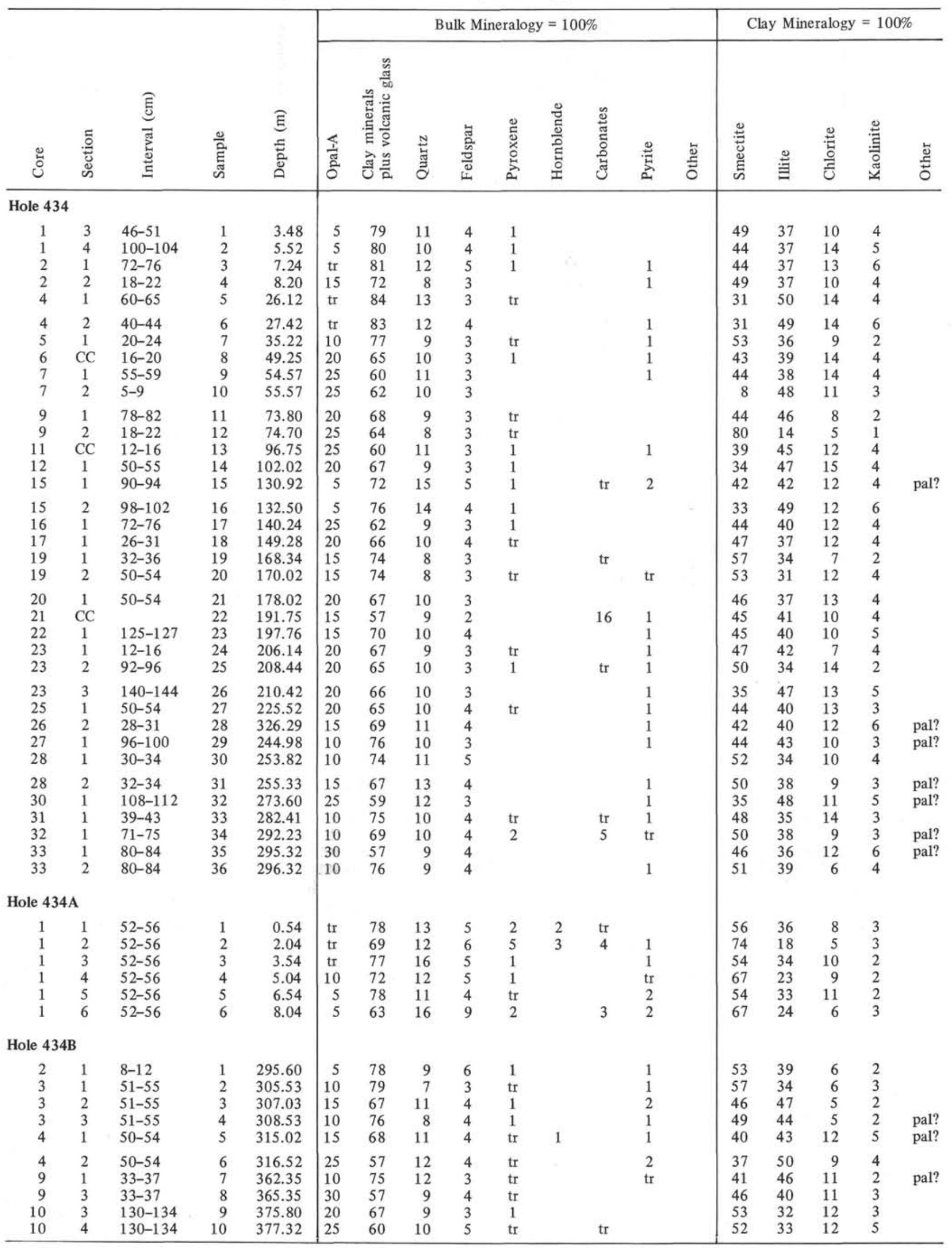


TABLE 4 - Continued

\begin{tabular}{|c|c|c|c|c|c|c|c|c|c|c|c|c|c|c|c|c|c|c|}
\hline \multirow[b]{2}{*}{ ن } & \multirow[b]{2}{*}{ 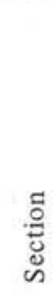 } & \multirow[b]{2}{*}{ 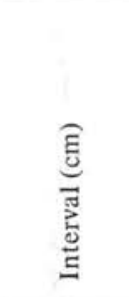 } & \multirow[b]{2}{*}{ 若 } & \multirow[b]{2}{*}{ 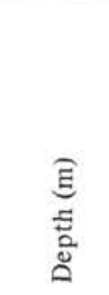 } & \multicolumn{9}{|c|}{ Bulk Mineralogy $=100 \%$} & \multicolumn{5}{|c|}{ Clay Mineralogy $=100 \%$} \\
\hline & & & & & $\frac{\nwarrow}{\tilde{~}}$ & 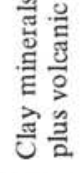 & 营 & 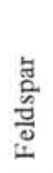 & 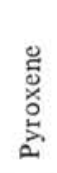 & 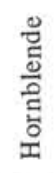 & 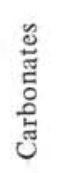 & $\stackrel{\Xi}{\frac{2}{5}}$ & $\stackrel{\text { 总 }}{0}$ & 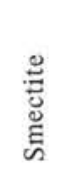 & $\stackrel{\Xi}{\Xi}$ & $\begin{array}{l}\stackrel{0}{0} \\
\text { 율 }\end{array}$ & 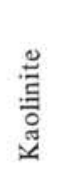 & 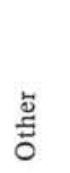 \\
\hline \multicolumn{5}{|c|}{ Hole 434B (cont.) } & & & & & & & & & & & & & & \\
\hline $\begin{array}{l}10 \\
10 \\
11 \\
15 \\
15\end{array}$ & $\begin{array}{l}5 \\
6 \\
1 \\
1 \\
2\end{array}$ & $\begin{array}{l}130-134 \\
70-74 \\
72-76 \\
40-44 \\
40-44\end{array}$ & $\begin{array}{l}11 \\
12 \\
13 \\
14 \\
15\end{array}$ & $\begin{array}{l}378.82 \\
380.32 \\
381.74 \\
418.42 \\
519.92\end{array}$ & $\begin{array}{l}20 \\
20 \\
20 \\
20 \\
25\end{array}$ & $\begin{array}{l}66 \\
65 \\
65 \\
65 \\
59\end{array}$ & $\begin{array}{l}11 \\
11 \\
11 \\
12 \\
12\end{array}$ & $\begin{array}{l}3 \\
4 \\
3 \\
3 \\
3\end{array}$ & $\begin{array}{l}1 \\
\text { tr }\end{array}$ & & & 1 & & $\begin{array}{l}52 \\
44 \\
53 \\
33 \\
36\end{array}$ & $\begin{array}{l}32 \\
37 \\
33 \\
46 \\
48\end{array}$ & $\begin{array}{l}12 \\
13 \\
11 \\
14 \\
11\end{array}$ & $\begin{array}{l}4 \\
6 \\
3 \\
7 \\
5\end{array}$ & $\begin{array}{l}\text { pal? } \\
\text { pal? } \\
\text { pal? }\end{array}$ \\
\hline $\begin{array}{l}15 \\
16 \\
16 \\
16 \\
17\end{array}$ & $\begin{array}{l}4 \\
1 \\
2 \\
4 \\
1\end{array}$ & $\begin{array}{l}40-44 \\
52-56 \\
52-56 \\
52-56 \\
72-76\end{array}$ & $\begin{array}{l}16 \\
17 \\
18 \\
19 \\
20\end{array}$ & $\begin{array}{l}422.92 \\
428.04 \\
429.54 \\
432.54 \\
437.74\end{array}$ & $\begin{array}{l}30 \\
35 \\
40 \\
35 \\
25\end{array}$ & $\begin{array}{l}57 \\
52 \\
48 \\
51 \\
60\end{array}$ & $\begin{array}{r}9 \\
9 \\
9 \\
10 \\
10\end{array}$ & $\begin{array}{l}3 \\
3 \\
3 \\
3 \\
3\end{array}$ & $\begin{array}{l}\operatorname{tr} \\
1\end{array}$ & & $\operatorname{tr}$ & $\begin{array}{l}1 \\
1 \\
\operatorname{tr} \\
1 \\
1\end{array}$ & & $\begin{array}{l}23 \\
32 \\
21 \\
34 \\
44\end{array}$ & $\begin{array}{l}57 \\
46 \\
54 \\
47 \\
42\end{array}$ & $\begin{array}{l}14 \\
14 \\
19 \\
15 \\
11\end{array}$ & $\begin{array}{l}6 \\
8 \\
6 \\
4 \\
3\end{array}$ & $\begin{array}{l}\text { pal? } \\
\text { pal? } \\
\text { pal? } \\
\text { pal? } \\
\text { pal? }\end{array}$ \\
\hline $\begin{array}{l}19 \\
19 \\
20 \\
24 \\
24\end{array}$ & $\begin{array}{l}1 \\
2 \\
1 \\
1 \\
2\end{array}$ & $\begin{array}{l}80-84 \\
70-74 \\
52-56 \\
31-35 \\
31-35\end{array}$ & $\begin{array}{l}21 \\
22 \\
23 \\
24 \\
25\end{array}$ & $\begin{array}{l}456.82 \\
458.32 \\
466.04 \\
504.83 \\
506.33\end{array}$ & $\begin{array}{r}5 \\
\text { tr } \\
15 \\
5 \\
5\end{array}$ & $\begin{array}{l}78 \\
79 \\
68 \\
80 \\
80\end{array}$ & $\begin{array}{l}13 \\
13 \\
13 \\
12 \\
12\end{array}$ & $\begin{array}{l}4 \\
4 \\
4 \\
3 \\
3\end{array}$ & $\operatorname{tr}$ & & 4 & & & $\begin{array}{l}53 \\
46 \\
34 \\
55 \\
53\end{array}$ & $\begin{array}{l}39 \\
43 \\
48 \\
38 \\
38\end{array}$ & $\begin{array}{r}6 \\
8 \\
13 \\
5 \\
6\end{array}$ & $\begin{array}{l}2 \\
3 \\
5 \\
2 \\
3\end{array}$ & $\begin{array}{l}\text { pal? } \\
\text { pal? }\end{array}$ \\
\hline $\begin{array}{l}25 \\
25 \\
25 \\
26 \\
26\end{array}$ & $\begin{array}{l}1 \\
2 \\
3 \\
1 \\
2\end{array}$ & $\begin{array}{l}110-114 \\
110-114 \\
110-114 \\
61-65 \\
61-65\end{array}$ & $\begin{array}{l}26 \\
27 \\
28 \\
29 \\
30\end{array}$ & $\begin{array}{l}515.12 \\
516.62 \\
518.12 \\
524.13 \\
525.63\end{array}$ & $\begin{array}{l}10 \\
15 \\
15 \\
15 \\
15\end{array}$ & $\begin{array}{l}74 \\
71 \\
71 \\
67 \\
69\end{array}$ & $\begin{array}{l}12 \\
11 \\
11 \\
12 \\
13\end{array}$ & $\begin{array}{l}4 \\
3 \\
3 \\
4 \\
3\end{array}$ & tr & & & 1 & & $\begin{array}{l}51 \\
49 \\
50 \\
58 \\
59\end{array}$ & $\begin{array}{l}41 \\
42 \\
40 \\
34 \\
34\end{array}$ & $\begin{array}{l}6 \\
6 \\
8 \\
5 \\
7\end{array}$ & $\begin{array}{l}2 \\
3 \\
2 \\
3 \\
2\end{array}$ & \\
\hline $\begin{array}{l}28 \\
32 \\
33 \\
34 \\
34\end{array}$ & $\begin{array}{l}1 \\
1 \\
1 \\
1 \\
2\end{array}$ & $\begin{array}{l}52-56 \\
66-70 \\
82-86 \\
52-56 \\
52-56\end{array}$ & $\begin{array}{l}31 \\
32 \\
33 \\
34 \\
35\end{array}$ & $\begin{array}{l}543.04 \\
581.18 \\
590.84 \\
600.04 \\
601.54\end{array}$ & $\begin{array}{l}\text { tr } \\
15 \\
15 \\
15 \\
15\end{array}$ & $\begin{array}{l}58 \\
66 \\
70 \\
71 \\
69\end{array}$ & $\begin{array}{l}10 \\
11 \\
11 \\
10 \\
12\end{array}$ & $\begin{array}{l}3 \\
3 \\
3 \\
4 \\
4\end{array}$ & & & $\begin{array}{r}29 \\
5\end{array}$ & 1 & & $\begin{array}{l}58 \\
46 \\
40 \\
46 \\
51\end{array}$ & $\begin{array}{l}34 \\
43 \\
45 \\
42 \\
39\end{array}$ & $\begin{array}{r}6 \\
6 \\
12 \\
9 \\
7\end{array}$ & $\begin{array}{l}2 \\
5 \\
3 \\
3 \\
3\end{array}$ & \\
\hline $\begin{array}{l}35 \\
36\end{array}$ & $\begin{array}{l}1 \\
1\end{array}$ & $\begin{array}{l}82-86 \\
11-15\end{array}$ & $\begin{array}{l}36 \\
37\end{array}$ & $\begin{array}{l}609.84 \\
618.63\end{array}$ & $\begin{array}{l}20 \\
25\end{array}$ & $\begin{array}{l}65 \\
61\end{array}$ & $\begin{array}{l}11 \\
10\end{array}$ & $\begin{array}{l}4 \\
3\end{array}$ & & & & & & $\begin{array}{l}46 \\
25\end{array}$ & $\begin{array}{l}36 \\
53\end{array}$ & $\begin{array}{l}12 \\
16\end{array}$ & $\begin{array}{l}6 \\
6\end{array}$ & \\
\hline
\end{tabular}

\section{Site 436, Hole 436 (Table 6, Figure 8)}

The lithological units established for Site 436 cannot be clearly differentiated by comparing the different groups of components. The only exception is Unit IIIA, which is highest in clay mineral (plus volcanic glass) content and lower in opal-A concentration than all other units. In addition, Unit IIIA contains nontronite and clinoptilolite, which do not occur in other units.

If, however, the relative percentages of the different clay mineral groups are considered, we see a change in the transition zone between Units IB and IA. The chlorite/kaolinite ratio (Figure 13) increases more or less gradually from the bottom of lithological Unit II to the top of Sub-unit IB. Within Sub-unit IA the ratio remains more or less constant.

Another subdivision based on the illite/smectite ratio can be made within Unit IA at the Pliocene/Pleistocene boundary. Above 80 meters, the ratio increases until it reaches its highest values in the youngest sediments (Figure 14). At this site quartz and feldspar concentrations are also generally higher in the Pleistocene than in older sediments. Rhodochrosite is restricted to the upper part of Sub-unit IIIA, Unit II, and parts of Sub-unit IB. Pyrite can only be detected by $x$-ray methods in the Pleistocene section.
Site 438, Holes 438, 438A, and 438B (Table 7, Figure 9)

At this site the different groups of components show considerable changes with depth. The most pronounced change occurs with opal-A, the concentration of which ranges from about 0 at a depth of 1000 meters to around 80 per cent at about $800 \mathrm{~m}$. Above 950 meters, the average concentration amounts to 42 per cent. From about 100 to 0 meters (Lithological Unit I), the opal content decreases from 50 per cent to 5 per cent. Clay minerals plus volcanic glass fluctuate between 6 and 63 per cent, with an average at 33 per cent. The quartz concentration is more or less constant (around 20 per cent), whereas feldspar shows a clear enrichment in Lithological Unit I (average 15 per cent) as compared with an average of 6 per cent for other units.

The different clay mineral groups show a bipartition in their relative percentages. Above 660 meters (middle Miocene/upper Miocene boundary) the average smectite percentage is 39 per cent, whereas below this depth percentages are considerably higher (average 58 per cent). The chlorite concentrations are higher above 660 meters (average 16 per cent) and distinctly lower below this depth. The kaolinite percentage exhibits a general tendency to increase from bottom to top. The chlorite/ kaolinite ratio (Figure 15) shows an abrupt change be- 




Figure 6. Bulk composition and clay mineralogy, Site 434. 
TABLE 5

Bulk Composition and Clay Mineralogy, Site 435

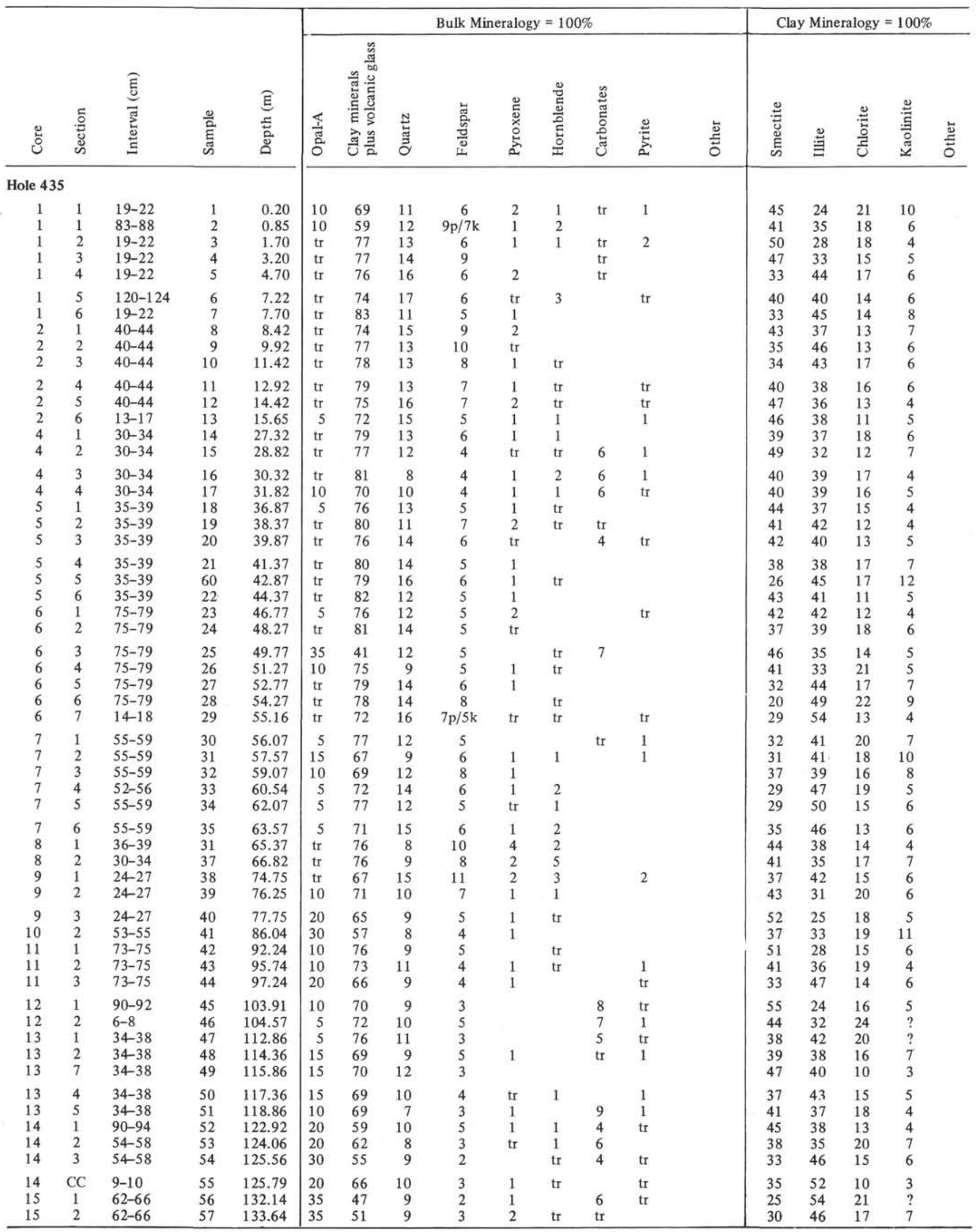


TABLE 5 - Continued

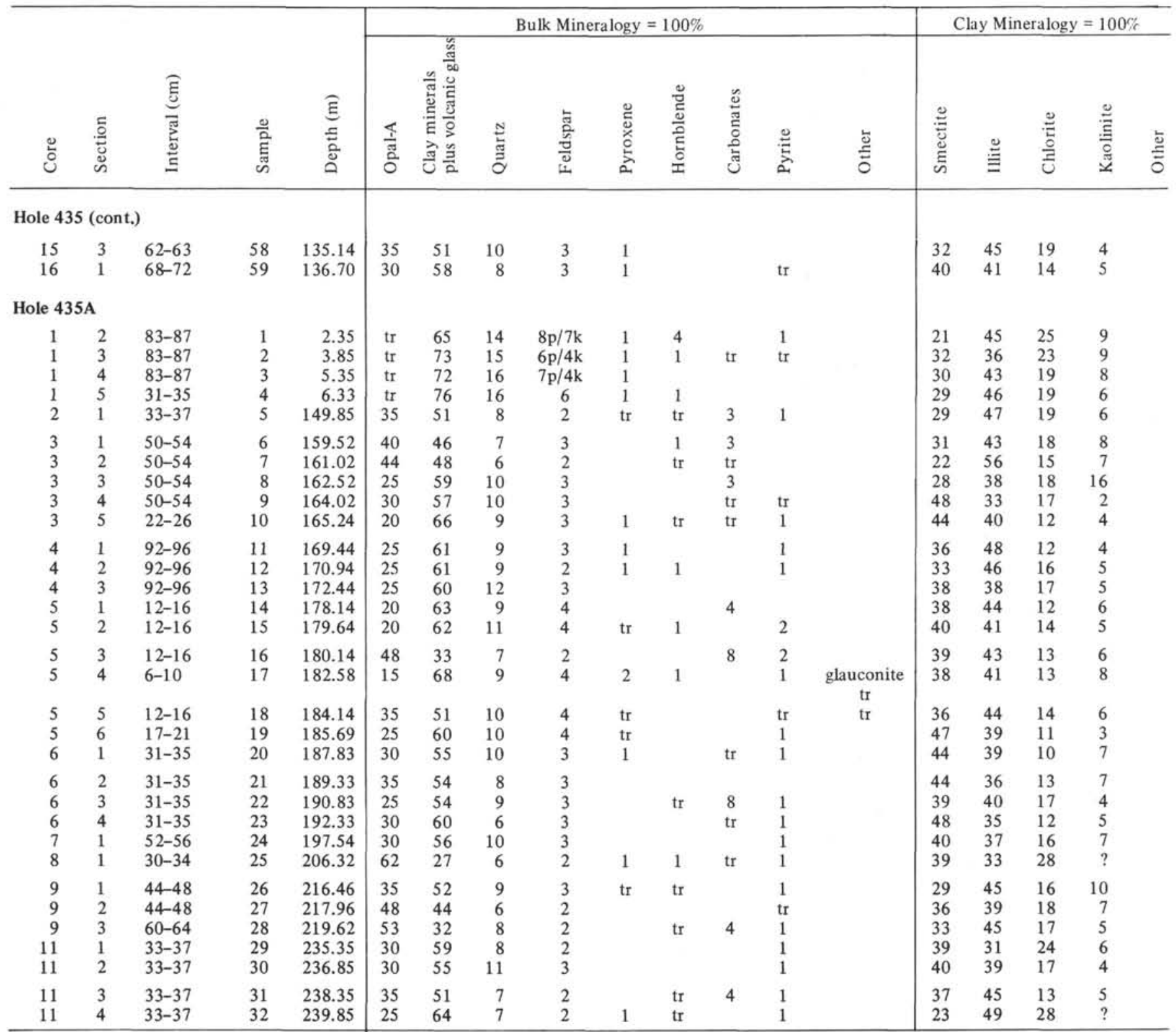

tween 750 and 700 meters. Above 700 meters, the ratio is high, with a slight decrease toward the top. From 1000 meters to 750 meters, the ratio decreases rapidly. Between 590 and 370 meters, the (001)-illite and -smectite peaks are asymmetrical, which indicates some mixed layering (illite layers in smectite and smectite layers in illite). Palygorskite occurs in small amounts in depths below 600 meters. Pyroxene and hornblende are most abundant in the uppermost lithological unit (Unit I).

\section{Site 439, Hole 439 (Table 8, Figure 10)}

Sample material was recovered from 870 meters to 1091 meters only. The sequence is characterized by an increase in the quartz and feldspar concentrations from top to bottom. Quartz concentrations reach 50 per cent, feldspar concentration, 35 per cent. Clay minerals (plus volcanic glass) decrease correspondingly. Opal-A is present only to a depth of 1000 meters (as in Site 438).
Opal-CT occurs in a distinct zone between 930 and 995 meters. Clinoptilolite is found together with opal-CT in the same zone but extends much deeper - to 1050 meters. Pyrite is relatively abundant, especially in Lithological Unit V.

Within the different clay mineral groups, there are considerable fluctuations, mainly in the smectite/illite ratio. Chlorite increases from top to bottom; kaolinite is not present in all samples. Carbonates are present below 1030 meters.

Site 440, Holes 440, 440A, and 440B (Table 9, Figure 11)

As in Site 435, a bipartition can be made by the properties of the two main components: opal-A and clay minerals plus volcanic glass. Above 350 meters (Pleistocene, Lithological Units IIA and I), opal-A concentrations are consistently low and clay minerals plus 



AGE LITH. UNIT

Figure 7. Bulk composition and clay mineralogy, Site 435.

volcanic glass correspondingly high. Below 350 meters, opal-A increases sharply at the expense of clay minerals plus volcanic glass and remains high down to a depth of 760 meters. Only below this depth can a decrease be observed. Quartz and feldspar concentrations are also generally higher above 350 meters than below.

\section{Site 441, Holes 441, 441A, and 441B (Table 10)}

The 11 samples which were received from this site cannot be seen as representative for the 687 meters of sediment. On the whole, this site resembles Site 434; however, from the bottom to 340 meters, the $>63-\mu$ fraction consists mainly of pumice pebbles. Because of the small number of samples, no figure is presented.

\section{General Trends in Composition}

According to their present location with respect to the Japanese Islands, the sites can be subdivided into three groups: (A) Sites 438 and 439, situated between 1547.5 meters and 1656 meters, a relatively shallow water depth on the deep sea terrace, closest to the island of Honshu; (B) Sites 434, 435, 440, and 441, on the inner trench slope, with an intermediate distance from Honshu and in deeper water (3401-5986 m); (C) Site 436, farthest from the islands and located on the outer rise at a water depth of 5240 meters. Varying composition may be expected because of the different location of the sites with relation to the source area, the Japanese Islands.
The average percentages of each component were calculated for each stratigraphic unit in the three groups. The numerical values are given in Table 11; Figures 12 through 16 are the graphical representation.

\section{Lateral Trends}

\section{Quartz and Feldspar and the Quartz/Feldspar Ratio} (Figures 12 and 13)

Pleistocene: By far the highest concentrations are found in Group A. A continuous decrease is seen from Group A to Group C. The quartz/feldspar ratio increases from A to B to C, although the increase from B to $\mathrm{C}$ is less pronounced.

Pliocene: A decrease in concentration from Group A to Group $\mathrm{C}$ is still visible but less pronounced. The quartz/feldspar ratio remains more or less constant.

Upper Miocene: As in the Pliocene, a less pronounced decrease in concentration occurs from Group A to Group C; the quartz/feldspar ratio is also more or less constant.

Middle Miocene: Here again there is a decrease from Group A to Group C. The quartz/feldspar ratio increases from A to C.

Clay Minerals and Volcanic Glass; Relative Percentages of Clay Mineral Groups (Figure 14)

In the Pleistocene, Pliocene, and upper Miocene, there is a general increasing trend from A to B to C. In the middle Miocene the concentrations are much higher in Group $\mathrm{C}$ than in Group A. 
TABLE 6

Bulk Composition and Clay Mineralogy, Site 436

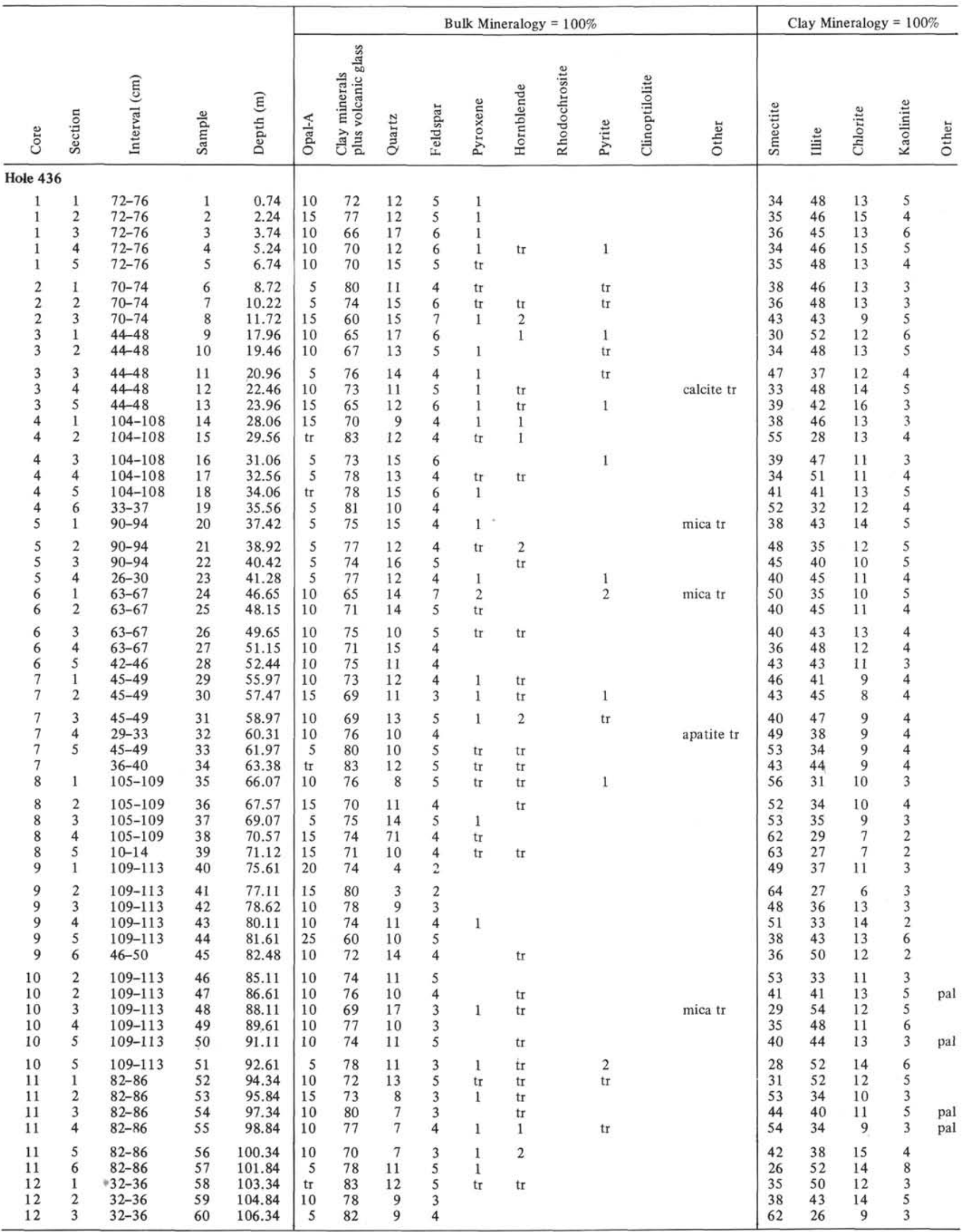


TABLE 6 - Continued

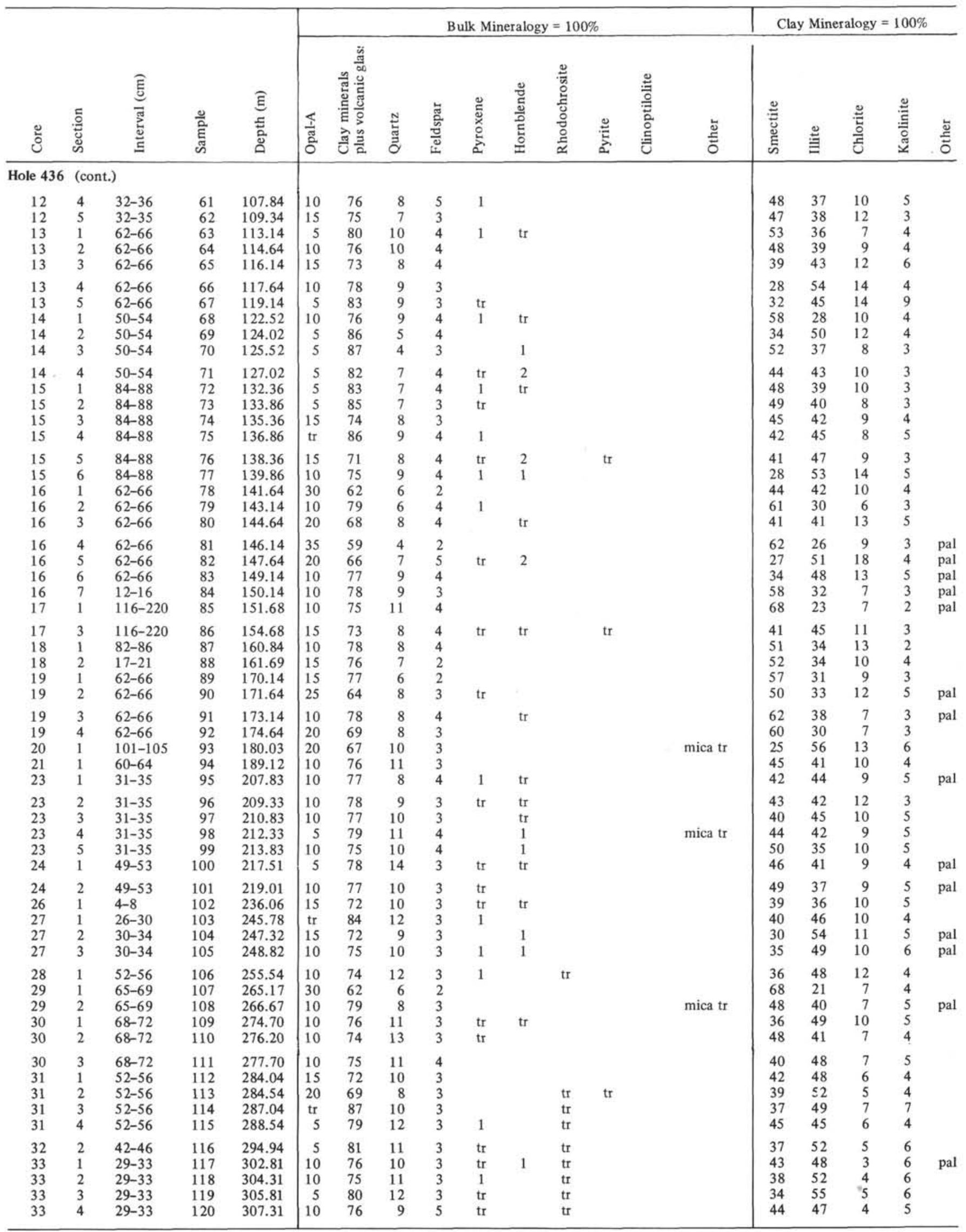




\begin{tabular}{|c|c|c|c|c|c|c|c|c|c|c|c|c|c|c|c|c|c|c|c|}
\hline \multirow[b]{2}{*}{ ๖ั } & \multirow[b]{2}{*}{  } & \multirow[b]{2}{*}{$\begin{array}{l}\text { E्E } \\
\frac{\text { J }}{2} \\
\text { E }\end{array}$} & \multirow[b]{2}{*}{ 总 } & \multirow[b]{2}{*}{$\begin{array}{l}\hat{\Xi} \\
\text { 吉 } \\
\text { ఏ. }\end{array}$} & \multicolumn{10}{|c|}{ Bulk Mineralogy $=100 \%$} & \multicolumn{5}{|c|}{ Clay Mineralogy $=100 \%$} \\
\hline & & & & & $\frac{5}{0}$ & 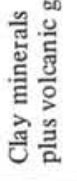 & 莺 & $\begin{array}{l}\text { 营 } \\
\frac{0}{0} \\
\frac{0}{0} \\
-1\end{array}$ & 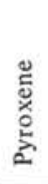 &  & 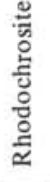 & ह & 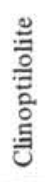 & 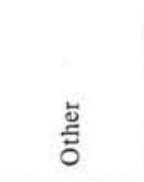 & 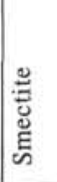 & $\stackrel{\Xi}{\Xi}$ & $\frac{\stackrel{2}{5}}{\frac{0}{d}}$ & 駦 & $\frac{\text { }}{5}$ \\
\hline \multicolumn{20}{|c|}{ Hole 436 (cont.) } \\
\hline $\begin{array}{l}33 \\
33 \\
33 \\
34 \\
34\end{array}$ & $\begin{array}{l}5 \\
6 \\
7 \\
1 \\
2\end{array}$ & $\begin{array}{l}29-33 \\
29-33 \\
23-27 \\
49-53 \\
49-53\end{array}$ & $\begin{array}{l}121 \\
122 \\
123 \\
124 \\
125\end{array}$ & $\begin{array}{l}308.81 \\
310.31 \\
311.75 \\
312.51 \\
314.01\end{array}$ & $\begin{array}{c}15 \\
20 \\
15 \\
\operatorname{tr} \\
10\end{array}$ & $\begin{array}{l}72 \\
72 \\
71 \\
86 \\
76\end{array}$ & $\begin{array}{r}8 \\
6 \\
10 \\
11 \\
11\end{array}$ & $\begin{array}{l}4 \\
2 \\
3 \\
3 \\
3\end{array}$ & $\begin{array}{c}1 \\
\text { tr } \\
1 \\
\text { tr }\end{array}$ & & $\begin{array}{l}\mathrm{tr} \\
\mathrm{tr} \\
\mathrm{tr} \\
\mathrm{tr} \\
\mathrm{tr}\end{array}$ & $\mathrm{tr}$ & & & $\begin{array}{l}33 \\
37 \\
34 \\
33 \\
37\end{array}$ & $\begin{array}{l}58 \\
52 \\
53 \\
56 \\
53\end{array}$ & $\begin{array}{l}3 \\
5 \\
6 \\
5 \\
4\end{array}$ & $\begin{array}{l}6 \\
2 \\
7 \\
6 \\
6\end{array}$ & \\
\hline $\begin{array}{l}34 \\
34 \\
34 \\
34 \\
34\end{array}$ & $\begin{array}{l}3 \\
4 \\
5 \\
6 \\
7\end{array}$ & $\begin{array}{l}49-53 \\
49-53 \\
49-53 \\
49-53 \\
17-21\end{array}$ & $\begin{array}{l}126 \\
127 \\
128 \\
129 \\
130\end{array}$ & $\begin{array}{l}315.51 \\
317.01 \\
318.51 \\
320.01 \\
321.19\end{array}$ & $\begin{array}{c}5 \\
5 \\
\text { tr } \\
\text { tr } \\
10\end{array}$ & $\begin{array}{l}81 \\
81 \\
87 \\
87 \\
76\end{array}$ & $\begin{array}{l}11 \\
11 \\
10 \\
10 \\
11\end{array}$ & $\begin{array}{l}3 \\
3 \\
3 \\
3 \\
3\end{array}$ & & & $\begin{array}{l}\mathrm{tr} \\
\mathrm{tr} \\
\mathrm{tr} \\
\mathrm{tr} \\
\mathrm{tr}\end{array}$ & & & & $\begin{array}{l}44 \\
40 \\
40 \\
31 \\
31\end{array}$ & $\begin{array}{l}46 \\
50 \\
51 \\
60 \\
58\end{array}$ & $\begin{array}{l}5 \\
4 \\
4 \\
4 \\
6\end{array}$ & $\begin{array}{l}5 \\
6 \\
5 \\
5 \\
5\end{array}$ & pal \\
\hline $\begin{array}{l}35 \\
35 \\
35 \\
35 \\
36\end{array}$ & $\begin{array}{l}1 \\
2 \\
3 \\
4 \\
1\end{array}$ & $\begin{array}{l}56-60 \\
56-60 \\
56-60 \\
56-60 \\
16-20\end{array}$ & $\begin{array}{l}131 \\
132 \\
133 \\
134 \\
135\end{array}$ & $\begin{array}{l}322.08 \\
323.58 \\
325.08 \\
326.58 \\
331.18\end{array}$ & $\begin{array}{l}10 \\
20 \\
\text { tr } \\
\text { tr } \\
20\end{array}$ & $\begin{array}{l}76 \\
64 \\
84 \\
85 \\
67\end{array}$ & $\begin{array}{l}11 \\
12 \\
12 \\
12 \\
11\end{array}$ & $\begin{array}{l}3 \\
3 \\
3 \\
3 \\
2\end{array}$ & $\begin{array}{l}1 \\
1 \\
\operatorname{tr} \\
\operatorname{tr}\end{array}$ & tr & $\begin{array}{l}1 \\
\mathrm{tr} \\
\mathrm{tr} \\
\mathrm{tr} \\
\mathrm{tr}\end{array}$ & & & & $\begin{array}{l}38 \\
45 \\
37 \\
36 \\
36\end{array}$ & $\begin{array}{l}51 \\
45 \\
55 \\
54 \\
53\end{array}$ & $\begin{array}{l}6 \\
5 \\
3 \\
5 \\
4\end{array}$ & $\begin{array}{l}5 \\
5 \\
5 \\
5 \\
7\end{array}$ & \\
\hline $\begin{array}{l}36 \\
36 \\
36 \\
36 \\
36\end{array}$ & $\begin{array}{l}2 \\
3 \\
4 \\
5 \\
6\end{array}$ & $\begin{array}{l}16-20 \\
16-20 \\
16-20 \\
16-20 \\
16-20\end{array}$ & $\begin{array}{l}136 \\
137 \\
138 \\
139 \\
140\end{array}$ & $\begin{array}{l}332.68 \\
334.18 \\
335.68 \\
337.18 \\
338.68\end{array}$ & $\begin{array}{r}10 \\
10 \\
5 \\
5 \\
\mathrm{tr}\end{array}$ & $\begin{array}{l}75 \\
75 \\
79 \\
80 \\
87\end{array}$ & $\begin{array}{l}12 \\
12 \\
13 \\
11 \\
10\end{array}$ & $\begin{array}{l}3 \\
3 \\
3 \\
3 \\
2\end{array}$ & $\begin{array}{l}\mathrm{tr} \\
1 \\
1\end{array}$ & & $\begin{array}{l}\mathrm{tr} \\
\mathrm{tr} \\
\mathrm{tr} \\
\mathrm{tr} \\
\mathrm{tr}\end{array}$ & & & & $\begin{array}{l}37 \\
32 \\
46 \\
36 \\
37\end{array}$ & $\begin{array}{l}53 \\
60 \\
42 \\
55 \\
53\end{array}$ & $\begin{array}{l}3 \\
2 \\
5 \\
3 \\
3\end{array}$ & $\begin{array}{l}7 \\
6 \\
7 \\
6 \\
7\end{array}$ & $\begin{array}{l}\text { pal } \\
\text { pal }\end{array}$ \\
\hline $\begin{array}{l}36 \\
37 \\
37 \\
37 \\
37\end{array}$ & $\begin{array}{l}7 \\
1 \\
2 \\
3 \\
4\end{array}$ & $\begin{array}{l}16-20 \\
66-67 \\
66-67 \\
66-67 \\
66-67\end{array}$ & $\begin{array}{l}141 \\
142 \\
143 \\
144 \\
145\end{array}$ & $\begin{array}{l}340.18 \\
341.16 \\
342.66 \\
344.16 \\
345.66\end{array}$ & $\begin{array}{r}\operatorname{tr} \\
5 \\
5 \\
5 \\
5\end{array}$ & $\begin{array}{l}87 \\
82 \\
83 \\
83 \\
83\end{array}$ & $\begin{array}{r}10 \\
10 \\
10 \\
9 \\
10\end{array}$ & $\begin{array}{l}2 \\
3 \\
2 \\
3 \\
2\end{array}$ & 1 & & $\begin{array}{l}\mathrm{tr} \\
\mathrm{tr} \\
\mathrm{tr} \\
\mathrm{tr} \\
1\end{array}$ & $\mathrm{tr}$ & & & $\begin{array}{l}35 \\
24 \\
31 \\
43 \\
33\end{array}$ & $\begin{array}{l}56 \\
66 \\
56 \\
46 \\
57\end{array}$ & $\begin{array}{l}3 \\
4 \\
6 \\
5 \\
4\end{array}$ & $\begin{array}{l}6 \\
6 \\
7 \\
6 \\
6\end{array}$ & $\begin{array}{l}\text { pal + } \\
+ \\
+\end{array}$ \\
\hline $\begin{array}{l}37 \\
37 \\
37 \\
38 \\
38\end{array}$ & $\begin{array}{l}5 \\
6 \\
7 \\
1 \\
2\end{array}$ & $\begin{array}{l}66-67 \\
66-67 \\
14-18 \\
62-66 \\
62-66\end{array}$ & $\begin{array}{l}146 \\
147 \\
148 \\
149 \\
150\end{array}$ & $\begin{array}{l}347.16 \\
348.66 \\
349.66 \\
350.64 \\
352.14\end{array}$ & $\begin{array}{l}10 \\
15 \\
10 \\
10 \\
10\end{array}$ & $\begin{array}{l}79 \\
75 \\
79 \\
80 \\
79\end{array}$ & $\begin{array}{l}9 \\
7 \\
9 \\
8 \\
9\end{array}$ & $\begin{array}{l}2 \\
2 \\
2 \\
2 \\
2\end{array}$ & $\begin{array}{l}1 \\
1 \\
\text { tr }\end{array}$ & & $\begin{array}{l}\text { tr } \\
\text { tr } \\
\text { tr } \\
\text { tr } \\
\text { tr }\end{array}$ & & & & $\begin{array}{l}31 \\
80 \\
40 \\
58 \\
63\end{array}$ & $\begin{array}{l}56 \\
16 \\
50 \\
35 \\
31\end{array}$ & $\begin{array}{l}3 \\
1 \\
3 \\
1 \\
1\end{array}$ & $\begin{array}{r}10 \\
3 \\
7 \\
6 \\
5\end{array}$ & $\begin{array}{l}\mathrm{pal}+ \\
\mathrm{pal}+\end{array}$ \\
\hline $\begin{array}{l}38 \\
38 \\
38 \\
38 \\
38\end{array}$ & $\begin{array}{l}3 \\
4 \\
5 \\
6 \\
7\end{array}$ & $\begin{array}{l}62-66 \\
62-66 \\
62-66 \\
62-66 \\
22-26\end{array}$ & $\begin{array}{l}151 \\
152 \\
153 \\
154 \\
155\end{array}$ & $\begin{array}{l}353.64 \\
355.14 \\
356.64 \\
358.14 \\
359.24\end{array}$ & $\begin{array}{r}10 \\
10 \\
10 \\
5 \\
5\end{array}$ & $\begin{array}{l}81 \\
80 \\
79 \\
81 \\
83\end{array}$ & $\begin{array}{r}7 \\
8 \\
9 \\
11 \\
10\end{array}$ & $\begin{array}{l}2 \\
2 \\
2 \\
3 \\
2\end{array}$ & $\begin{array}{l}\mathrm{tr} \\
\mathrm{tr}\end{array}$ & & $\begin{array}{l}\mathrm{tr} \\
\mathrm{tr} \\
\mathrm{tr} \\
\mathrm{tr} \\
\mathrm{tr}\end{array}$ & & & & $\begin{array}{l}55 \\
58 \\
49 \\
65 \\
68\end{array}$ & $\begin{array}{l}37 \\
35 \\
46 \\
30 \\
24\end{array}$ & $\begin{array}{l}1 \\
1 \\
1 \\
1 \\
2\end{array}$ & $\begin{array}{l}7 \\
6 \\
4 \\
4 \\
6\end{array}$ & \\
\hline $\begin{array}{l}39 \\
39 \\
39 \\
39 \\
39\end{array}$ & $\begin{array}{l}1 \\
2 \\
3 \\
4 \\
5\end{array}$ & $\begin{array}{l}52-56 \\
52-56 \\
52-56 \\
52-56 \\
52-56\end{array}$ & $\begin{array}{l}156 \\
157 \\
158 \\
159 \\
160\end{array}$ & $\begin{array}{l}360.04 \\
361.54 \\
363.04 \\
364.54 \\
366.04\end{array}$ & $\begin{array}{r}\mathrm{tr} \\
5 \\
5 \\
\operatorname{tr} \\
\mathrm{tr}\end{array}$ & $\begin{array}{l}90 \\
83 \\
82 \\
87 \\
88\end{array}$ & $\begin{array}{r}7 \\
8 \\
10 \\
10 \\
9\end{array}$ & $\begin{array}{l}3 \\
3 \\
3 \\
3 \\
3\end{array}$ & 1 & & $\begin{array}{l}\mathrm{tr} \\
\mathrm{tr} \\
\mathrm{tr} \\
\mathrm{tr} \\
\mathrm{tr}\end{array}$ & & $\begin{array}{l}\mathrm{tr} \\
\mathrm{tr} \\
\mathrm{tr}\end{array}$ & & $\begin{array}{l}76 \\
65 \\
42 \\
56 \\
36\end{array}$ & $\begin{array}{l}20 \\
30 \\
51 \\
37 \\
50\end{array}$ & $\begin{array}{c}\mathrm{tr} \\
\mathrm{tr} \\
\mathrm{tr} \\
2 \\
3\end{array}$ & $\begin{array}{r}4 \\
5 \\
7 \\
5 \\
11\end{array}$ & \\
\hline 39 & 6 & $52-56$ & 161 & 367.54 & 5 & 84 & 9 & 2 & & & tr & & & $\begin{array}{c}\text { nontronite } \\
\mathrm{tr}\end{array}$ & 41 & 44 & 4 & 11 & \\
\hline 40 & 2 & $44-48$ & 162 & 370.96 & $\operatorname{tr}$ & 89 & 9 & 2 & & & $\operatorname{tr}$ & & & $\begin{array}{c}\text { nontronite } \\
\mathrm{tr}\end{array}$ & 32 & 54 & 6 & 8 & \\
\hline 40 & 7 & $12-16$ & 163 & 378.14 & tr & 91 & 7 & 2 & & & & & & & 59 & 35 & 2 & 5 & \\
\hline
\end{tabular}

Relative changes in the composition of the clay minerals are expressed clearly only in the percentages of the minor clay minerals, chlorite and kaolinite.

From Groups A to C, the relative amount of chlorite decreases in all formations investigated. Kaolinite shows a similar decrease only in the Pleistocene and Pliocene (Figure 15).

\section{Opal-A (Figure 16)}

Pleistocene: The (low) concentration of opal-A remains almost constant over all three groups.
Pliocene and upper Miocene: From Group $\mathrm{A}$ to Group B a relatively low decrease and from B to C a greater decrease can be observed.

In the middle Miocene a very sudden decrease occurs in Group C.

\section{Pyroxene and Hornblende (Figure 13)}

Pleistocene: A very sharp decrease in concentration occurs between Groups A and B and between B and C.

Pliocene and upper Miocene: Similar to the Pleistocene, a decrease from A to B to C is present, though much less pronounced. 


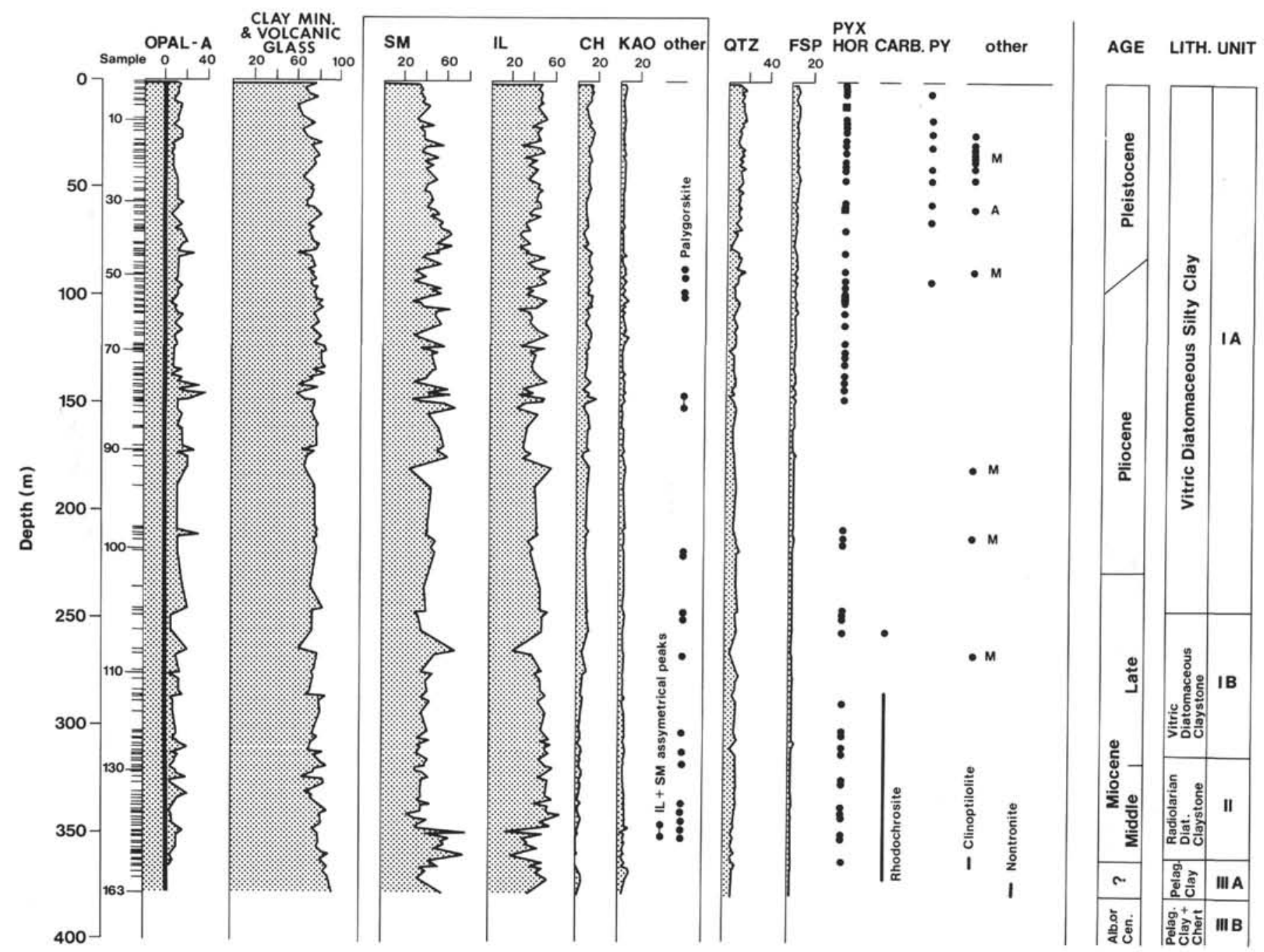

Figure 8. Bulk composition and clay mineralogy, Site 436.

In the middle Miocene, a decrease from Group A to Group C is clearly visible.

\section{Pyrite (Figure 13)}

In the Pleistocene, Pliocene, and the upper and middle Miocene, pyrite decreases from Group A to Group C.

\section{Carbonates (Figure 13)}

In the Pleistocene, carbonates are highest in Group $\mathrm{A}$, sharply decreasing in $\mathrm{B}$, and occur only in traces in Group C. In the Pliocene, carbonates generally decrease gradually from A to B; in Group C only traces are to be found.

In the upper Miocene, carbonates occur in traces in Groups A and C and in small percentages in Group B.

\section{Vertical Trends}

\section{Quartz and Feldspar, Quartz/Feldspar Ratio (Figures 12 and 13)}

From the Pliocene to the upper Miocene, similar trends are seen in Groups A, B, and C. Values are highest in the Pleistocene, lowest in the Pliocene, and in- termediate in the upper Miocene. The middle Miocene values in Groups $\mathrm{A}$ and $\mathrm{C}$ are similar to those of the Pliocene.

The Group A quartz and feldspar concentrations in the lower Miocene are comparable with those of the Pleistocene. The Oligocene concentrations are by far the highest. In Group $\mathrm{C}$ the Cretaceous red clay has a quartz plus feldspar concentration similar to that of the middle Miocene and Pliocene. The quartz/feldspar ratio increased in all three groups from Pleistocene to middle Miocene. In the lower Miocene and Oligocene of Group A, the ratio decreases again. In Group C, Cretaceous sediments exhibit a ratio similar to that of the upper Miocene.

\section{Clay Minerals and Volcanic Glass; Relative Percentages of the Clay Mineral Groups (Figures 14 and 15)}

The clay minerals and volcanic glass vary least with age in Group C; however, there is a weak tendency to increase with depth. In Groups A and B, Pleistocene sediments are highest in clay minerals and volcanic glass, Pliocene and Miocene sediments have somewhat smaller concentrations; and Oligocene sediments in Group A have the lowest values. 
TABLE 7

Bulk Composition and Clay Mineralogy, Site 438

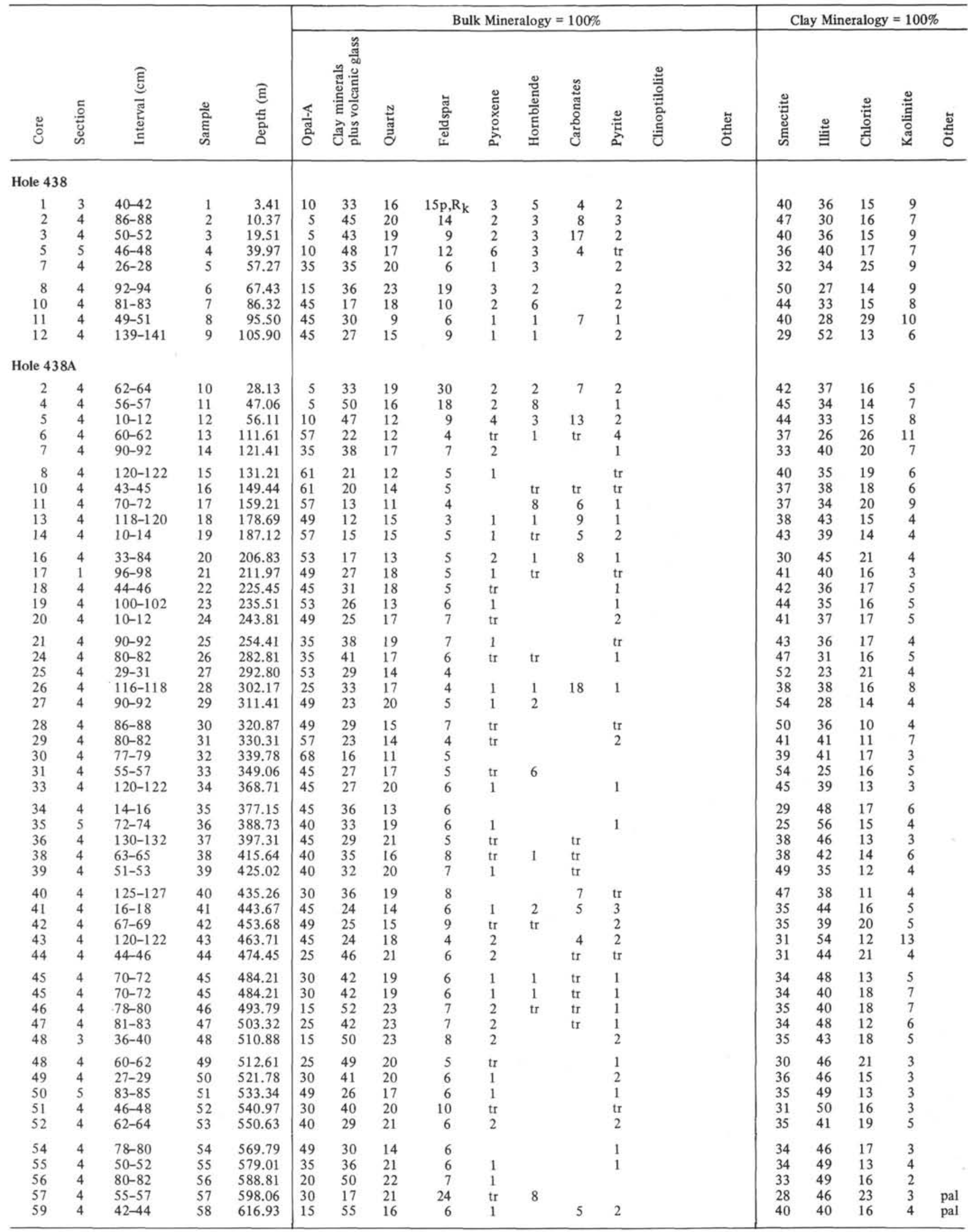


TABLE 7 - Continued

\begin{tabular}{|c|c|c|c|c|c|c|c|c|c|c|c|c|c|c|c|c|c|c|c|}
\hline \multirow[b]{2}{*}{ ¿ } & \multirow[b]{2}{*}{ 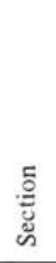 } & \multirow[b]{2}{*}{ 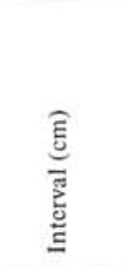 } & \multirow[b]{2}{*}{ 尝 } & \multirow[b]{2}{*}{ 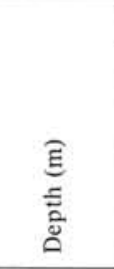 } & \multicolumn{10}{|c|}{ Bulk Mineralogy $=100 \%$} & \multicolumn{5}{|c|}{ Clay Mineralogy $=100 \%$} \\
\hline & & & & & $\begin{array}{l}\frac{\nwarrow}{\tilde{I}} \\
\text { Oे }\end{array}$ & 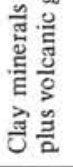 & 䔍 & 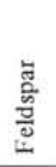 & 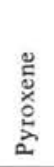 &  & 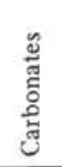 & $\frac{2}{5}$ & 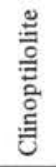 & 岕 &  & 弚 &  & 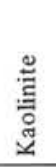 & . \\
\hline 63 & 1 & $64-66$ & 59 & 651.15 & 30 & 44 & 18 & 6 & 1 & & $\mathrm{tr}$ & 1 & & & 40 & 40 & 16 & 4 & pal \\
\hline 64 & 4 & $81-83$ & 60 & 664.82 & 61 & 17 & 15 & 5 & tr & $\operatorname{tr}$ & $\mathrm{tr}$ & 2 & & & 40 & 40 & 17 & 3 & pal \\
\hline 65 & 4 & $114-116$ & 61 & 674.65 & 45 & 23 & 17 & 6 & tr & $\mathrm{tr}$ & 6 & 3 & & & 52 & 33 & 13 & 2 & pal \\
\hline 66 & 2 & $46-48$ & 62 & 680.47 & O-tr & 13 & 2 & & & & 85 & & & & 46 & 42 & 8 & 2 & pal \\
\hline 68 & 4 & $83-86$ & 63 & 702.85 & 35 & 38 & 19 & 6 & 1 & $\mathrm{tr}$ & & 1 & & & 43 & 37 & 17 & 3 & pal \\
\hline 70 & 4 & $46-48$ & 64 & 721.47 & 49 & 23 & 20 & 6 & 1 & tr & $\mathrm{tr}$ & 1 & & & 54 & 30 & 12 & 4 & pal \\
\hline 71 & 4 & $105-107$ & 65 & 731.56 & 40 & 39 & 17 & 4 & tr & & & tr & & & 63 & 26 & 8 & 3 & pal \\
\hline 82 & 4 & $123-125$ & 71 & 836.24 & 35 & 48 & 12 & 5 & & tr & & tr & & & 59 & 29 & 8 & 4 & \\
\hline 84 & 4 & $130-132$ & 72 & 855.31 & 35 & 41 & 19 & 5 & & tr & & tr & & & 64 & 28 & 5 & 3 & \\
\hline 85 & 4 & $6-8$ & 73 & 863.57 & 40 & 39 & 15 & 5 & & tr & & 1 & & & 51 & 35 & 10 & 4 & \\
\hline \multicolumn{20}{|c|}{ Hole 438B } \\
\hline 4 & & $123-126$ & 74 & 859.04 & 45 & 34 & 16 & 4 & & $\operatorname{tr}$ & & 1 & & & 75 & 19 & 4 & 2 & \\
\hline 7 & 3 & $62-65$ & 75 & 885.13 & 40 & 36 & 19 & 4 & & tr & & 1 & & & 70 & 23 & 5 & 2 & \\
\hline 12 & 4 & $121-122$ & 76 & 934.41 & 40 & 28 & 19 & 7 & 2 & tr & 4 & tr & & & 60 & 29 & 8 & 3 & \\
\hline 17 & 2 & $82-84$ & 77 & 978.03 & 5 & 58 & 25 & 11 & & & & 1 & & $\underset{\mathrm{tI}}{\text { glauconite }}$ & 57 & 30 & 11 & 2 & pal \\
\hline 18 & 4 & $88-92$ & 78 & 990.60 & 5 & 56 & 24 & 13 & & & & tr & 2 & $\underset{\mathrm{tr}}{\text { glauconite }}$ & 63 & 26 & 9 & 2 & \\
\hline 19 & 4 & $143-146$ & 79 & 1000.74 & tr & 63 & 23 & 12 & & & & & 2 & $\begin{array}{c}\text { glauconite } \\
\text { tr }\end{array}$ & 62 & 24 & 12 & 2 & \\
\hline
\end{tabular}

A vertical change in the relative clay mineral composition is best expressed in the chlorite and kaolinite percentages. In the Pleistocene, Pliocene, and upper Miocene, the chlorite concentration remains constant in Group A and increases in Groups B and C. In Group A the chlorite content decreases sharply in the middle Miocene. Kaolinite shows a more or less steady increase from Miocene to Pleistocene in Groups A and B, whereas in Group C the reverse is to be observed - a steady decrease from Cretaceous to Pleistocene.

\section{Opal-A (Figure 16)}

The vertical sequence in Groups $\mathrm{A}$ and $\mathrm{B}$ are characterized by a sharp increase of opal-A concentrations in the Pliocene. In Group A they are five times and in Group B about three times higher than in the Pleistocene. In Group C only a small increase is to be observed. In the upper and middle Miocene the concentrations are only slightly smaller than in the Pliocene. In the lower Miocene of Group A a great reduction can be observed. In Group $C$ the Cretaceous sediments exhibit extremely low concentrations.

\section{Pyroxene and Hornblende (Figure 13)}

In all groups these two minerals show a pronounced continuous decrease from Pleistocene to middle Mio- cene. In Group A in the lower Miocene higher values again occur which increase in the Oligocene sediments. In Group C, during the Cretaceous, only traces of pyroxene and hornblende were deposited.

\section{Pyrite (Figure 13)}

In Group A, there is a general trend similar to that of pyroxene and hornblende: A decrease occurs from Pleistocene to middle Miocene and increases again from lower Miocene to Oligocene. In Group B, pyrite levels remain constant. In Group $\mathrm{C}$, pyrite in measurable quantities occurs only in the Pleistocene; in older formations only traces were observed.

\section{Carbonates (Figure 13)}

In Group A, carbonate concentrations are highest in the Pleistocene, much lower in the Pliocene, and occur only in traces in the upper and middle Miocene. In the lower Miocene and Oligocene, concentrations are similar to those of the Pliocene. In Group B, concentrations are equally high in all penetrated formations. In Group $\mathrm{C}$, carbonates are virtually absent except for traces of rhodochrosite in the upper Miocene and Cretaceous. 
Rhodochrosite, Siderite, Nontronite, Clinoptilolite, and Opal-CT

These minerals, which were formed by diagenetic processes, generally occur only in very small amounts in distinct zones within specific groups (Plate 1).

Rhodochrosite occurs in larger, repeatedly twinned crystals (Plate 1) only in the upper Miocene and Cretaceous of Group C.

Siderite occurs only in Group A in the lower Miocene in connection with reworked Cretaceous radiolarians.

Nontronite is also restricted to Group C, in the Cretaceous, and shows spherical aggregates (Plate 1).

Clinoptilolite occurs in all groups: in Group A in the lower Miocene and Oligocene; in Group B in the upper Miocene; in Group C in the lowest part of the middle Miocene and Cretaceous. This mineral is present in all groups in the lower cores.

Opal-CT is restricted to the deep lower Miocene of Group A.

\section{Glauconite}

Glauconite is found as an authigenic mineral in fillings of radiolarians and the pores of pumice. In addition, singular grains without any attachment to other minerals occur. The highest amounts are to be found in Group A, in the Pleistocene and lower Miocene.

\section{Special Trends in Clay Mineralogy}

In this chapter attention is drawn to special mineralogical features occurring within the different groups of clay minerals.

\section{Chlorite/Kaolinite Ratio Variations at Sites $\mathbf{4 3 6}$ and $\mathbf{4 3 8}$}

Figure 17 clearly shows a gradual increase of the chlorite/kaolinite ratio at Site 436 from the bottom of Lithological Unit II - middle Miocene, underlain by pelagic oxyclay, Unit IIIA - to the top of Unit 1B upper section of upper Miocene - by a factor of about 10. This increase correlates positively with an increase of the rate of sedimentation within this section and a change of sediment color from darker to lighter colors -i.e., from dark brown via yellowish brown to greenish gray. In the zone of the gradual increase of the chlorite/ kaolinite ratio, authigenic rhodochrosite (Plate 1) occurs in larger crystals.

At Site 438 (Figure 18) clay sedimentation in the lower Miocene begins with a relatively high chlorite/ kaolinite ratio (6), which decreases continuously to a value of about 1 . At a depth of 745 meters (middle Miocene), between 745 and 665 meters, there is a sharp increase of about 1 to 6.5. Above this depth the ratio fluctuates around 3.5 with a general tendency to decrease toward the surface sediments.

\section{Illite/Smectite Ratio Variations at Site $\mathbf{4 3 6}$}

Figure 8 shows a clear decrease of the percentage of smectite at the expense of each of the other three clay mineral groups in the uppermost 80 meters (Pleistocene). Figure 19 illustrates the illite/smectite ratio of this section. The distribution of the single measurements confirms the general trend of an increasing ratio from bottom to top of the Pleistocene; however, the gradient is not constant. In the 50 to 30 meter interval a reverse trend seems to be indicated.

\section{“Sharpness" of the Glycolated (001) Smectite Peak at Site $\mathbf{4 3 4}$}

The method of determining the "crystallinity" of illite (for compilation see Dunoyer de Segonzac et al., 1968) was adapted and applied to the glycolated $17 \AA$ peak of smectite from Sites 434, 435, 436, 440, and 441 . The "sharpness" ratio of the peak is expressed by the ratio of the peak height above the background to the width of the peak at mid-height.

Figure 20 shows a very irregular vertical distribution of the ratios. However, if the minimum values are considered, four staggered groups of points can be differentiated for Site 434, which in itself shows the decreasing ratio from top to bottom. The same number of groups are to be seen in Figure 21, for Site 441. At Sites 435 and 436 the smectite peak changes continuously. At all sites, groups of similar thermal conductivity can be correlated with the smectite peaks.

\section{DISCUSSION OF RESULTS}

\section{General Trends in Bulk Composition}

Lateral Trends

\section{Pleistocene}

In general, the trend of clay minerals (plus volcanic glass) to increase continuously from Group A via Group $\mathrm{B}$ to Group $\mathrm{C}$ at the expense of quartz and feldspars, pyroxene and hornblende, pyrite, and carbonates reflects the position of the sites in relation to the main source area, the Japanese Island Arc. For example, relatively coarse-grained material rich in nonclay constituents is deposited closest to the islands, whereas finer-grained material rich in clay minerals is deposited farther seaward. Group B has an intermediate position between Group A and C. The lack of carbonates in Group C is due to the water depth; the sediment surface lies below the carbonate compensation depth.

The opal-A concentration shows no significant changes between the different groups. Pyrite enrichment in Group A is due to the higher rate of sedimentation, which prevents the complete oxidation of the organic matter.

\section{Pliocene}

The Pliocene exhibits the same trend as the youngest unit, except that opal-A concentration is generally higher, especially in Group A, and shows a steady decrease toward Group C via Group B.

\section{Upper Miocene}

The general trend of the Pliocene, including opal-A concentration, also occurs in the upper Miocene.

\section{Middle Miocene}

Once again we find a seaward decrease of quartz plus feldspars, pyroxene plus hornblende, pyrite and carbonates at the expense of clay minerals (plus volcanic glass). 


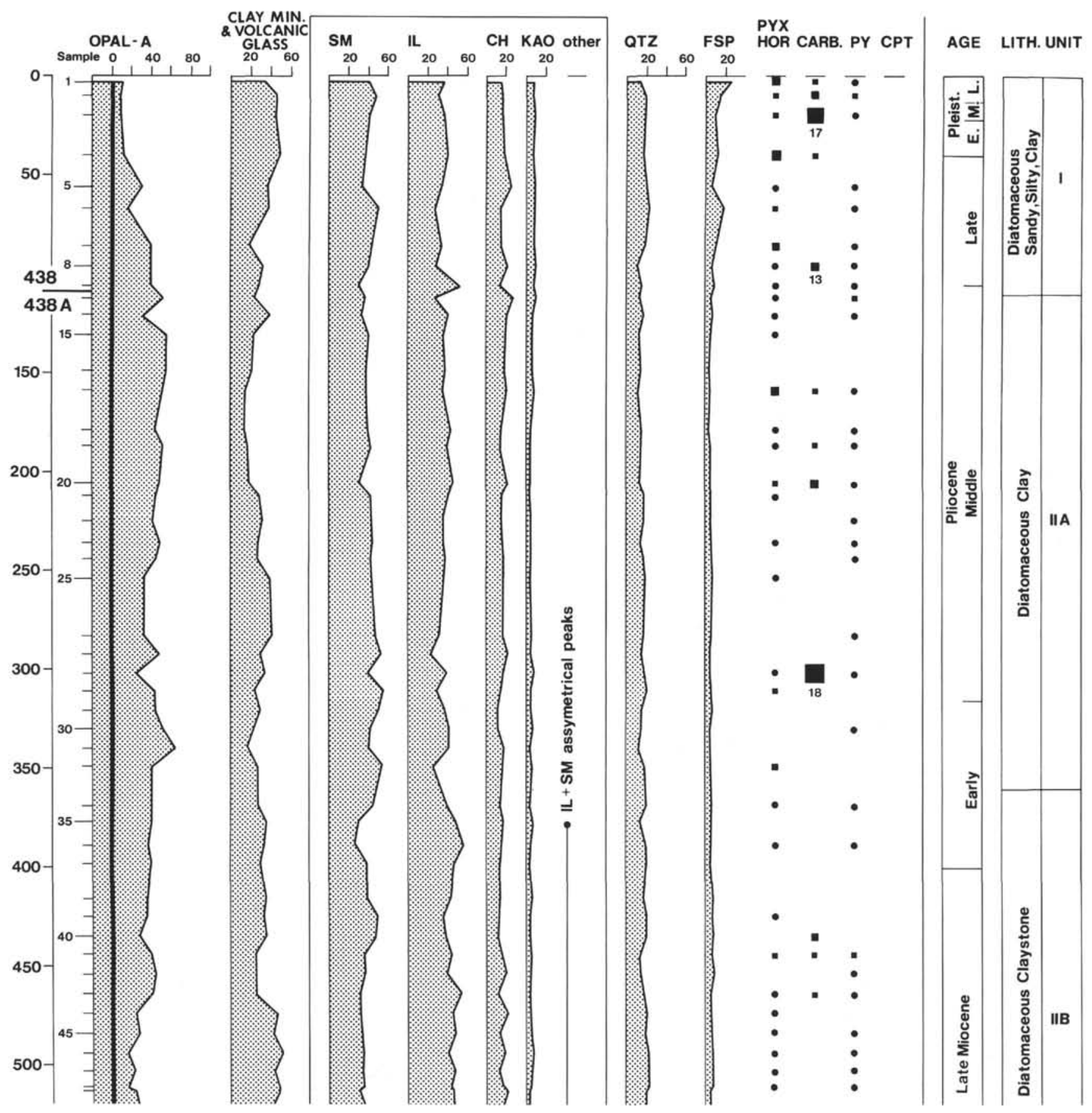




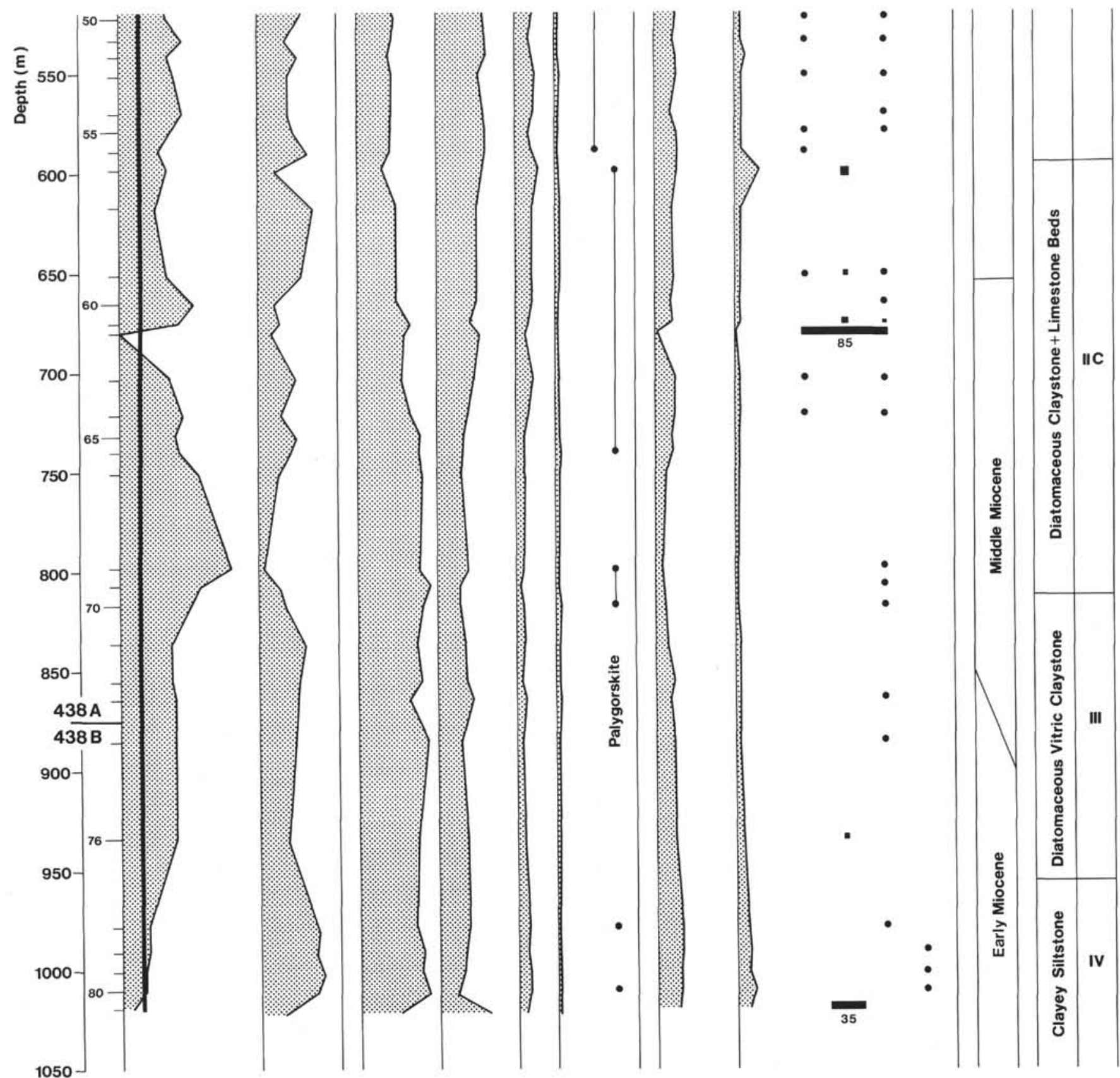

Figure 9. Bulk composition and clay mineralogy, Site 438. 
TABLE 8

Bulk Composition and Clay Mineralogy, Site 439

\begin{tabular}{|c|c|c|c|c|c|c|c|c|c|c|c|c|c|c|c|c|c|c|c|c|}
\hline \multirow[b]{2}{*}{ ัँّ } & \multirow[b]{2}{*}{ 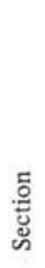 } & \multirow[b]{2}{*}{ 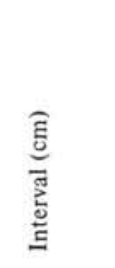 } & \multirow[b]{2}{*}{ 䒿 } & \multirow[b]{2}{*}{$\begin{array}{l}\text { छ } \\
\underline{\Xi} \\
\text { ڤั }\end{array}$} & \multicolumn{11}{|c|}{ Bulk Mineralogy $=100 \%$} & \multicolumn{5}{|c|}{ Clay Mineralogy $=100 \%$} \\
\hline & & & & & 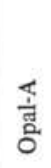 & 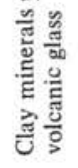 & 壳 & 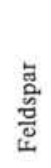 & & 节 & 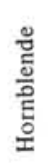 & 选 & $\stackrel{0}{2}$ & 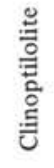 & 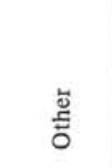 & 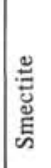 & $\stackrel{\Xi}{\Xi}$ & 䒿 & 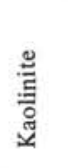 & 总 \\
\hline \multicolumn{5}{|c|}{ Hole 439} & & & & & & & & & & & Opal-CT & & & & & \\
\hline $\begin{array}{r}7 \\
8 \\
9 \\
10 \\
11\end{array}$ & $\begin{array}{l}4 \\
4 \\
4 \\
4 \\
4\end{array}$ & $\begin{array}{l}57-59 \\
65-67 \\
85-87 \\
51-53 \\
54-55\end{array}$ & $\begin{array}{l}1 \\
2 \\
3 \\
4 \\
5\end{array}$ & $\begin{array}{l}873.58 \\
883.16 \\
892.86 \\
902.02 \\
911.54\end{array}$ & $\begin{array}{l}20 \\
40 \\
25 \\
20 \\
20\end{array}$ & $\begin{array}{l}55 \\
38 \\
50 \\
52 \\
52\end{array}$ & $\begin{array}{l}15 \\
16 \\
18 \\
18 \\
10\end{array}$ & $\begin{array}{l}9 \\
5 \\
5 \\
6 \\
5\end{array}$ & & $\begin{array}{l}1 \\
1 \\
1 \\
1 \\
2\end{array}$ & $\begin{array}{l}1 \\
\operatorname{tr} \\
\operatorname{tr} \\
1 \\
3\end{array}$ & & $\begin{array}{l}1 \\
1 \\
2 \\
3\end{array}$ & & & $\begin{array}{l}60 \\
70 \\
60 \\
48 \\
56\end{array}$ & $\begin{array}{l}30 \\
21 \\
29 \\
41 \\
29\end{array}$ & $\begin{array}{r}7 \\
6 \\
7 \\
8 \\
11\end{array}$ & $\begin{array}{l}3 \\
3 \\
4 \\
3 \\
4\end{array}$ & \\
\hline $\begin{array}{l}13 \\
14 \\
15 \\
19 \\
21\end{array}$ & $\begin{array}{l}3 \\
3 \\
4 \\
1 \\
2\end{array}$ & $\begin{array}{l}45-47 \\
12-14 \\
3-9 \\
62-63 \\
75-77\end{array}$ & $\begin{array}{r}6 \\
7 \\
8 \\
9 \\
10\end{array}$ & $\begin{array}{l}928.96 \\
935.13 \\
939.56 \\
973.62 \\
994.26\end{array}$ & $\begin{array}{l}20 \\
10 \\
20 \\
10 \\
25\end{array}$ & $\begin{array}{l}12 \\
35 \\
28 \\
37 \\
13\end{array}$ & $\begin{array}{l}30 \\
25 \\
23 \\
23 \\
37\end{array}$ & $\begin{array}{r}24 \\
13 \\
12 \\
18 \\
9\end{array}$ & \multirow{2}{*}{ 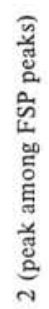 } & & $\begin{array}{l}2 \\
3 \\
1 \\
2 \\
\mathrm{tr}\end{array}$ & $\begin{array}{l}\mathrm{tr} \\
\mathrm{tr}\end{array}$ & $\begin{array}{l}1 \\
1 \\
2 \\
3 \\
2\end{array}$ & $\begin{array}{l}2 \\
4 \\
4 \\
3\end{array}$ & $\begin{array}{l}7 \\
7 \\
8 \\
5 \\
9\end{array}$ & $\begin{array}{l}28 \\
34 \\
70 \\
69 \\
68\end{array}$ & $\begin{array}{l}58 \\
50 \\
19 \\
21 \\
23\end{array}$ & $\begin{array}{r}14 \\
16 \\
11 \\
8 \\
9\end{array}$ & 2 & \\
\hline $\begin{array}{l}21 \\
22 \\
23 \\
24 \\
25\end{array}$ & $\begin{array}{l}4 \\
4 \\
1 \\
4 \\
2\end{array}$ & $\begin{array}{l}14-15 \\
102-104 \\
29-31 \\
32-33 \\
85-87\end{array}$ & $\begin{array}{l}11 \\
12 \\
13 \\
14 \\
15\end{array}$ & $\begin{array}{r}996.14 \\
1007.03 \\
1011.30 \\
1025.32 \\
1032.36\end{array}$ & $\begin{array}{r}15 \\
0 \\
0 \\
0 \\
0\end{array}$ & $\begin{array}{l}13 \\
32 \\
33 \\
19 \\
38\end{array}$ & $\begin{array}{l}42 \\
38 \\
44 \\
57 \\
37\end{array}$ & $\begin{array}{l}16 \\
22 \\
18 \\
19 \\
11\end{array}$ & & & $\begin{array}{l}2 \\
1 \\
\operatorname{tr}\end{array}$ & 3 & $\begin{array}{l}1 \\
2 \\
1 \\
3 \\
9\end{array}$ & $\begin{array}{l}\mathrm{tr} \\
2 \\
1 \\
\mathrm{tr} \\
\mathrm{tr}\end{array}$ & 11 & $\begin{array}{l}26 \\
68 \\
64 \\
50 \\
46\end{array}$ & $\begin{array}{l}51 \\
20 \\
25 \\
37 \\
36\end{array}$ & $\begin{array}{r}18 \\
9 \\
9 \\
13 \\
18\end{array}$ & $\begin{array}{l}5 \\
3 \\
2\end{array}$ & \\
\hline $\begin{array}{l}26 \\
27 \\
28 \\
30 \\
31\end{array}$ & $\begin{array}{l}4 \\
3 \\
2 \\
2 \\
3\end{array}$ & $\begin{array}{l}94-96 \\
12-15 \\
56-58 \\
15-17 \\
72-74\end{array}$ & $\begin{array}{l}16 \\
17 \\
18 \\
19 \\
20\end{array}$ & $\begin{array}{l}1044.95 \\
1051.13 \\
1060.57 \\
1079.16 \\
1090.73\end{array}$ & $\begin{array}{l}0 \\
0 \\
0 \\
0 \\
0\end{array}$ & $\begin{array}{l}25 \\
22 \\
35 \\
14 \\
18\end{array}$ & $\begin{array}{l}40 \\
44 \\
32 \\
36 \\
54\end{array}$ & $\begin{array}{l}23 \\
18 \\
24 \\
36 \\
21\end{array}$ & 总 & & $\begin{array}{l}3 \\
2 \\
3 \\
5\end{array}$ & $\begin{array}{r}3 \\
5 \\
4 \\
12\end{array}$ & $\begin{array}{l}2 \\
3 \\
\text { tr }\end{array}$ & $\begin{array}{l}2 \\
4 \\
\text { tr }\end{array}$ & & $\begin{array}{l}41 \\
54 \\
90 \\
44 \\
39\end{array}$ & $\begin{array}{r}40 \\
27 \\
7 \\
36 \\
39\end{array}$ & $\begin{array}{r}17 \\
16 \\
3 \\
18 \\
20\end{array}$ & $\begin{array}{r}2 \\
13 \\
2 \\
2\end{array}$ & \\
\hline
\end{tabular}
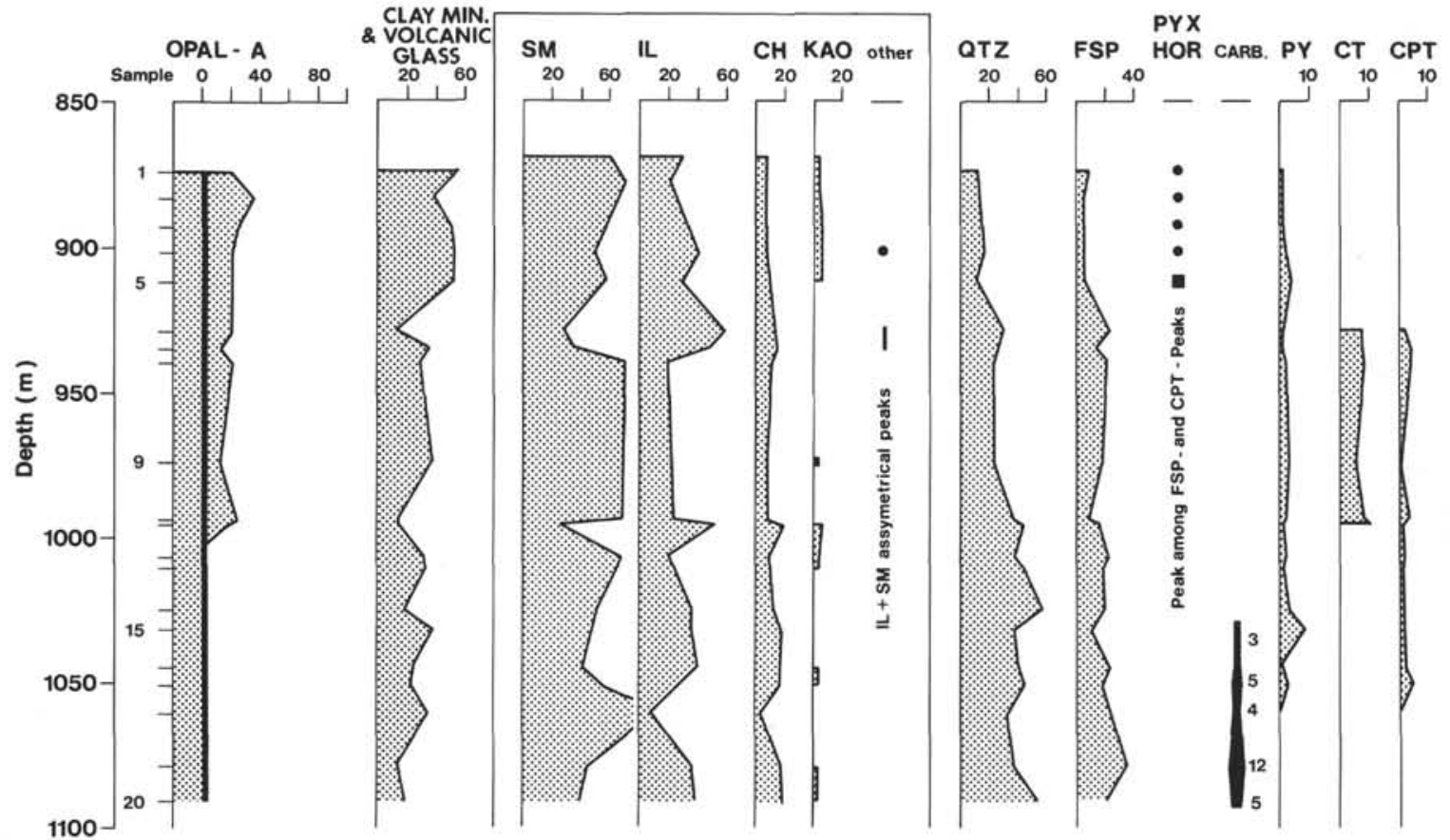

AGE LITH. UNIT


2020

Figure 10. Bulk composition and clay mineralogy, Site 439.

\section{Vertical Trends}

\section{Pleistocene to Middle Miocene}

The main constituents - clay minerals (plus volcanic glass) and quartz plus feldspar - show parallel fluctuations with age in all groups. These fluctuations in the terrigenous material are caused by a dilution with biogenic silica.

Pyroxene and hornblende decrease with age; the quartz/feldspar ratio increases. This phenonemon may be explained by one of two processes: (1) Diagenesis has dissolved part of the feldspar and pyroxene plus hornblende, or (2) the main portion of the feldspars and the 
TABLE 9

Bulk Composition and Clay Mineralogy, Site 440




TABLE 9 - Continued



bulk of pyroxene and hornblende are associated with pyroclastic material. In the present study the mineral distribution indicates an increase of volcanic activity since the middle Miocene.

Figure 22, a stratigraphic comparison of the average percentages of pyroxene plus hornblende with the number of ash layers per million years, seems to confirm Process (1). However, we detected no indication microscopically of diagenetic processes which affected either the volcanic glass or the feldspar and pyroxene plus hornblende. In each case these constituents had a "fresh" appearance, with no dissolution marks. The incongruity between the pyroxene plus hornblende concentrations and the number of ash layers is due to the different composition of the volcanic material: the ash layers of Pleistocene age have higher heavy mineral concentrations than the older strata. In addition, much of the ash was disseminated throughout the sediment so that ash layers are not necessarily proportional to the true flux of ash.

\section{Lower Miocene to Cretaceous}

In Group A an increase of quartz plus feldspars and pyroxene plus hornblende occurs in the lower Miocene and reaches a maximum in the Oligocene. This increase runs parallel with a change of the lithology. In the Oligocene, sediments consist of sandstone and siltstone, indicating very shallow water. Biogenic silica, already reduced in quantity in the lower Miocene, is totally absent in the Oligocene.

\section{Special Trends in Clay Mineralogy}

\section{Chlorite/Kaolinite Ratio at Site $\mathbf{4 3 8}$}

The chlorite/kaolinite ratio at Site 438 is characterized by the following trends: (1) a strong decrease during the complete lower Miocene up to the middle Miocene; (2) an extreme increase within the middle to the upper part of the middle Miocene; and (3) a weak (up- per part of the middle Miocene to the middle Pliocene), then a moderate, decrease of the ratio up to the Pleistocene. The trend of general decrease from bottom to top is interrupted by a reverse trend of the ratios limited to a few tens of meters of deposits. We explained as the results of effects associated with the submergence of the Oyashio ancient landmass (OAL), a subsided chain of islands in front of the present Japanese Islands which was situated between Site 438 and the present deep-sea trench (Figure 23). After the subsidence of the OAL below sea level, the position of Site 438 rapidly came under the influence of detritus of the Japan Island Arc, which is characterized by a high chlorite/kaolinite ratio. Metamorphic rocks, rich in chlorite, are very abundant on the Japan Island Arc (Tanaka and Nozawa, 1977).

Variations of relief in the respective source areas might be responsible for the general decrease of the chlorite/kaolinite ratio before and after the trend reversal. With the decrease in relief of a source area, mechanical weathering decreases (less chlorite), whereas chemical weathering and the formation of soil increase (more kaolinite).

The trend reversal in the chlorite/kaolinite ratio strongly supports the conclusion that the subsidence of the OAL took place during the middle Miocene.

\section{Chlorite/Kaolinite Ratio at Site $\mathbf{4 3 6}$}

Based on the chlorite/kaolinite ratio at Site 436, we can distinguish two sections: (1) a lower section with a strongly increasing ratio from the beginning to the middle Miocene up to the middle part of the Pliocene and (2) an upper section with a nearly constant ratio from the middle part of the Pliocene up to Recent sediments. At this site the variation of the ratio is caused by a decrease of kaolinite as well as by an increase of chlorite. As at Site 438 the Japan Island Arc and the OAL are considered source areas for the detrital sediment constituents in the upper part of Site 436. A high 
amount of chlorite reflects high relief in the source area (mechanical weathering), and increased amounts of kaolinite in the sediment reflect a low relief (formation of soil). Furthermore, Ratejew et al. (1966) show that kaolinite has its highest frequency in sediments near the equator, whereas toward the poles it decreases to a large extent.

The contribution of a source area generally decreases with distance to the site of deposition. Thus an increase in chlorite as well as a decrease of kaolinite are to be expected as the Pacific Plate moved to the Northwest.

Thus the strong increase of the chlorite/kaolinite ratio shows the drift of the position of Site 436 across the Pacific to its present site on the rise of the Japan Trench. A northwest direction can be assumed by the increase in chlorite and the decrease in kaolinite (Figure 24). This is in agreement with the calculations of Heezen et al. (1973). According to these authors the northward component of motion for the Pacific Plate amounts to 2 $\mathrm{cm}$ per year on an average and the westward component to $8 \mathrm{~cm}$ per year.

In the middle part of the Pliocene the chlorite/kaolinite ratio is the same as at Site 438. From this time on, the position of Site 436 is dominantly under the influence of detritus of the Japan Island Arc. The regressive trend created by a relative increase of kaolinite (formation of soil, decrease in relief) seen at Site 438 is counteracted by decreasing amounts of kaolinite associated with the northward component of drift; thus the ratio remains constant. In the lower part of the upper Miocene a regressive trend is probable. This may be caused by the decrease in relief of the Oyashio ancient landmass.

\section{Illite/Smectite Ratio in the Pleistocene of Site $\mathbf{4 3 6}$}

At Site 436 there was an increase of the illite/smectite ratio within the Pleistocene. The decrease of smectite is considered to be a result of dilution by other clay minerals (mainly illite). Similar conditions were already described at several places in the Pacific and Atlantic (Jacobs and Hays, 1972, and Jacobs, 1970).

The increase of the illite/smectite ratio can be explained by intensified mechanical weathering in conjunction with increased erosion, which results in a higher sedimentation rate. The variations of climate in the Pleistocene are believed to be responsible for the oscillations of the illite/smectite ratio.

\section{Early Diagenetic Changes}

The sharpness of the glycolated (001) smectite peak decreases generally in all sites from top to bottom, with one exception (authigenic formation of nontronite at Site 436). This phenomenon can be interpreted as an early diagenetic structural fixation of potassium in smectite; with increasing depth of burial a smectite-illite mixed layer is formed with increasing illite layering. Potassium can be derived from interstitial water and decomposition of feldspars. The increasing temperature must be considered as the main reason for the transformation of smectite. At Sites 435 and 436 the sharpness of the smectite peak changes continuously. On the other hand, at Sites 434, 440, and 441 a stepwise decrease occurs. The single steps are identical with steps of similar thermal conductivity. Thermal conductivity of a sediment is determined by water content and mechanical compaction (at constant lithology). The stepwise changes can be explained by the intensive tectonic processes which are assumed for the midslope terrace and the lower inner slope of the Japan Trench (Langseth and Okada, 1978; von Huene and Nasu, 1978). Faulting associated with overthrusting caused a change in the original sedimentary sequence. This is also suggested by repetition of several biostratigraphic zonations (Harper, this volume). As a result, we assume shear planes at the depths (in meters) of the following three positions.

\begin{tabular}{rrcc}
\hline Hole & 434 & $434 \mathrm{~B}^{\mathrm{a}}$ & $440 / 440 \mathrm{~A} / 440 \mathrm{~B}$ \\
\hline 90 & no core & 80 \\
281 & 310 & 245 \\
& no core & 521 & 605 \\
\hline
\end{tabular}

${ }^{\mathrm{a}}$ Hole 434B has a different position from Holes 434 and $434 \mathrm{~A}$, whereas $440,440 \mathrm{~A}$, and $440 \mathrm{~B}$ have the same position.

\section{ACKNOWLEDGMENTS}

We gratefully acknowledge the support given by the German Research Association (DFG). Special thanks are due to Andreas Sioulas and Ulrich Kästner for technical assistance.

\section{REFERENCES}

Biscaye, P. E., 1965. Mineralogy and sedimentation of recent deep-sea clay in the Atlantic Ocean and adjacent seas and oceans. Bull. Geol. Soc. Am., 76, 803-832.

Calvert, S. E., 1966. Accumulation of diatomaceous silica sediments in the Gulf of California. Bull. Geol. Soc. Am., 77, 569-596.

Chester, R., and Elderfield, H., 1968. The infrared determination of opal in siliceous deep-sea sediments. Geochim. Cosmochim. Acta, 32, 1128-1140.

Dunoyer de Segonzac, G., Ferrero, V., and Kubler, B., 1968. Sur la cristallinité de l'illite dans la diagénèse et l'anchimétamorphose. Sedimentology, 10, 137-143.

Goldberg, E. D., 1958. Determination of opal in marine sediments. J. Mar. Res., 17, 178-182.

Heezen, B. C., MacGregor, J. D., Foreman, H. P., Forristall, G. Z., Hekel, H., Hesse, R., Hoskins, R. H., Jones, E. J. W., Kaneps, A. G., Krasheninnikov, V. A., Okada, H., and Ruef, N. H., 1973. The Post Jurassic sedimentary sequence on the Pacific Plate; a kinematic interpretation of diachronous deposits. In Heezen, B. C., MacGregor, J. D., et al., Init. Repts. DSDP, 20: Washington (U.S. Govt. Printing Office), 725-738.

Jacobs, M. B., 1970. Clay mineral investigation of Cretaceous and Quaternary deep sea sediments of the North American Basin. J. Sed. Petrol., 40, 864-868.

Jacobs, M. B., and Hays, D., 1972. Paleoclimatic events indicated by mineralogical changes in deep-sea sediments. $J$. Sed. Petrol., 42, 889-898.

Langseth, M., and Okada, H., 1978. Near the Japan Trench transects begun. Geotimes, 23, 21-26.

Leinen, M., 1977. A normative calculation technique for determining opal in deep-sea sediments. Geochim. Cosmochim. Acta, 41, 671-676. 


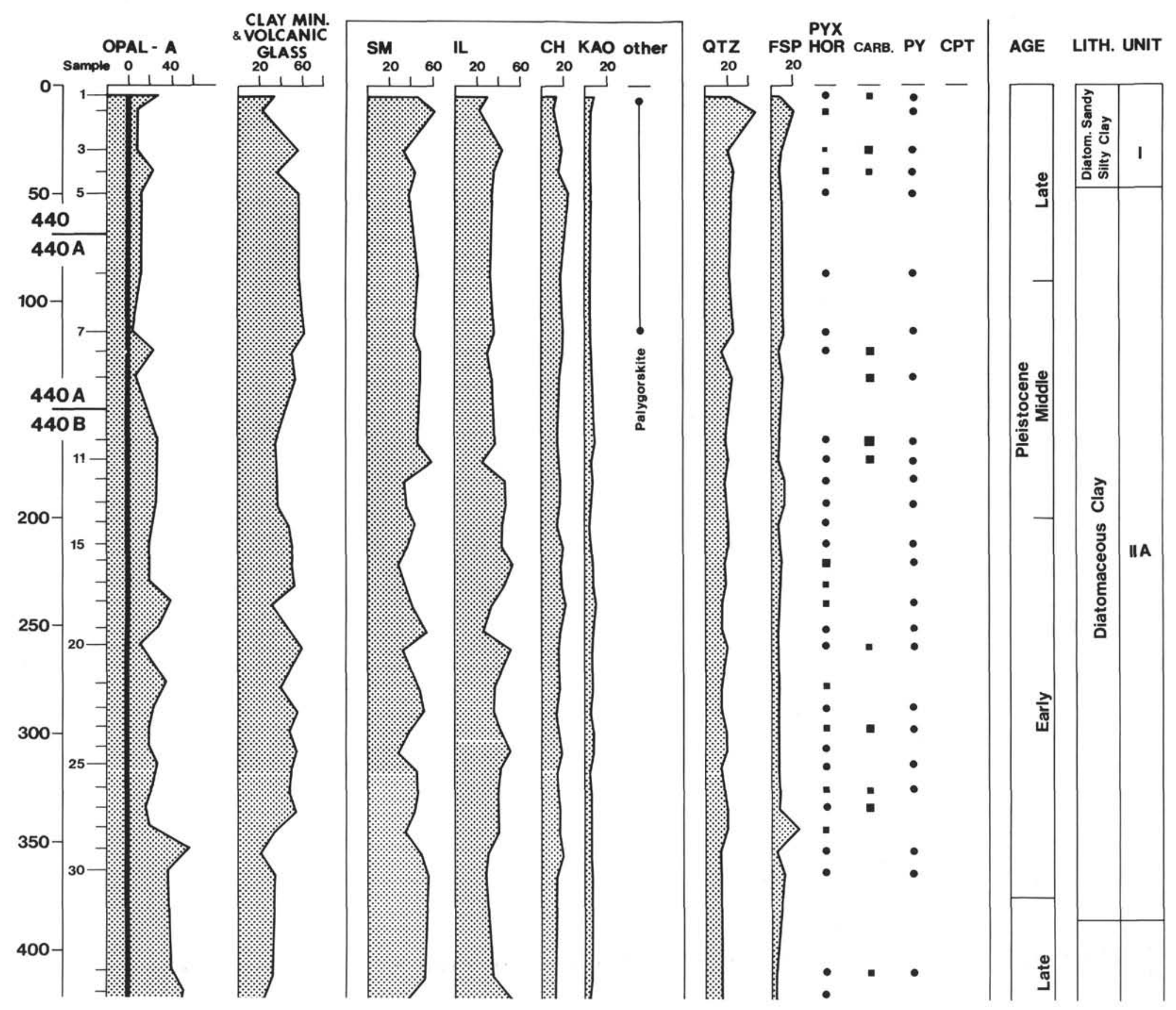



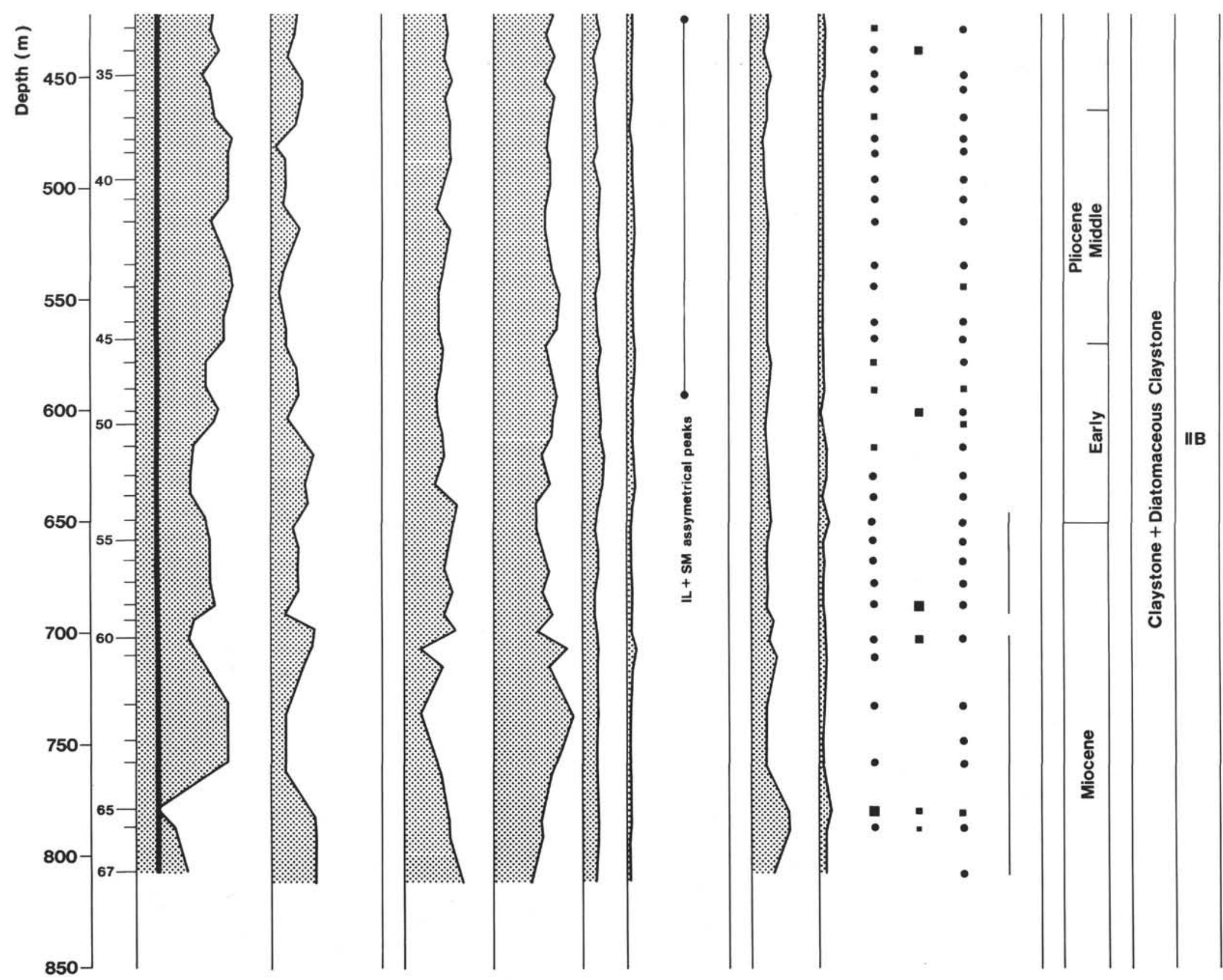
TABLE 10

Bulk Composition and Clay Mineralogy, Site 441



Mann, U., and Müller, G., in press. Mineralogy of the sedimentary sections encountered on Leg 55 (Sites 430-433), based on x-ray diffractometry. In Jackson, E. D., Koizumi, I., et al., Init. Repts. DSDP, 55: Washington (U.S. Govt., Printing Office).

1980. X-ray mineralogy of Deep Sea Drilling Project Legs 51 through 53, Western North Atlantic. In Donnelly, T., Francheteau, J., Bryan, W., Robinson, P., Flower, M., Salisbury, M. et al., Init. Repts. DSDP, 51, 52, 53, Pt. 2: Washington (U.S. Govt. Printing Office).

Müller, G., and Gastner, M., 1971. The "carbonate-bomb," a simple device for the determination of the carbonate con- tent in sediments, soils, and other mateials. Neue Jahrb. Mineral., 10, 466-469.

Ratejew, M. A., Gorbunowa, S. N., Lisitzin, A. P., and Nossow, G. J., 1966. Verteilung det Tonminerale in den Becken des Weltmeeres in Bezug auf die klimatischen Zonen. (russ.) Litologija i poljesnije iskopajemije, v. 3, pp. 3-23. In Fuchtbauer, H., and Müller, G. (Eds.), Sedimentgesteine (1970): Stuttgart (Schweizerbart-Verlag).

Tanaka, K., and Nozawa, T. (Eds.), 1977. Geology and Mineral Resources of Japan (Vol. 1), Geology: Tokyo (Geological Survey of Japan).

von Huene, R., and Nasu, N., 1978. Japan Trench Transected. Geotimes, 23, 16-20. 
TABLE 11

Average Percentages of the Different Components of Sediments for Each Stratigraphic Unit, Legs 56 and 57

\begin{tabular}{|c|c|c|c|c|}
\hline Component & Stratigraphic Unit & Group A & Group B & Group C \\
\hline Opal-A & $\begin{array}{l}\text { Pleistocene } \\
\text { Pliocene } \\
\text { upper Miocene } \\
\text { middle Miocene } \\
\text { lower Miocene } \\
\text { Oligocene } \\
\text { Cretaceous }\end{array}$ & $\begin{array}{r}9.0 \\
45.0 \\
32.4 \\
42.2 \\
15.0 \\
0\end{array}$ & $\begin{array}{r}9.1 \\
29.6 \\
25.6\end{array}$ & $\begin{array}{r}9.2 \\
11.3 \\
10.4 \\
7.1\end{array}$ \\
\hline $\begin{array}{l}\text { Clay } \\
\text { minerals } \\
\text { plus } \\
\text { Volcanic } \\
\text { Glass }\end{array}$ & $\begin{array}{l}\text { Pleistocene } \\
\text { Pliocene } \\
\text { upper Miocene } \\
\text { middle Miocene } \\
\text { lower Miocene } \\
\text { Oligocene } \\
\text { Cretaceous }\end{array}$ & $\begin{array}{l}40.4 \\
27.9 \\
37.5 \\
32.5 \\
36.6 \\
26.2\end{array}$ & $\begin{array}{l}65.1 \\
52.3 \\
52.4\end{array}$ & $\begin{array}{l}73.5 \\
75.6 \\
76.0 \\
80.2\end{array}$ \\
\hline $\begin{array}{l}\text { Quartz } \\
\text { plus } \\
\text { Feldspar }\end{array}$ & $\begin{array}{l}\text { Pleistocene } \\
\text { Pliocene } \\
\text { upper Miocene } \\
\text { middle Miocene } \\
\text { lower Miocene } \\
\text { Oligocene } \\
\text { Cretaceous }\end{array}$ & $\begin{array}{l}36.6 \\
22.2 \\
26.5 \\
19.0 \\
37.0 \\
64.9\end{array}$ & $\begin{array}{l}22.5 \\
15.4 \\
19.0\end{array}$ & $\begin{array}{l}16.6 \\
12.6 \\
13.2 \\
12.5\end{array}$ \\
\hline$\frac{\text { Quartz }}{\text { Feldspar }}$ & $\begin{array}{l}\text { Pleistocene } \\
\text { Pliocene } \\
\text { upper Miocene } \\
\text { middle Miocene } \\
\text { lower Miocene } \\
\text { Oligocene } \\
\text { Cretaceous }\end{array}$ & $\begin{array}{l}1.2 \\
2.8 \\
2.9 \\
3.1 \\
2.3 \\
2.2\end{array}$ & $\begin{array}{l}2.3 \\
3.0 \\
3.3\end{array}$ & $\begin{array}{l}2.6 \\
2.5 \\
3.3 \\
4.1\end{array}$ \\
\hline $\begin{array}{l}\text { Pyroxene } \\
\text { plus } \\
\text { Hornblende }\end{array}$ & $\begin{array}{l}\text { Pleistocene } \\
\text { Pliocene } \\
\text { upper Miocene } \\
\text { middle Miocene } \\
\text { lower Miocene } \\
\text { Oligocene } \\
\text { Cretaceous }\end{array}$ & $\begin{array}{r}6.2 \\
2.2 \\
1.5 \\
0.4 \\
1.5 \\
\sim 4\end{array}$ & $\begin{array}{l}1.9 \\
0.8 \\
0.6\end{array}$ & $\begin{array}{l}0.7 \\
0.5 \\
0.4\end{array}$ \\
\hline Pyrite & $\begin{array}{l}\text { Pleistocene } \\
\text { Pliocene } \\
\text { upper Miocene } \\
\text { middle Miocene } \\
\text { lower Miocene } \\
\text { Oligocene } \\
\text { Cretaceous }\end{array}$ & $\begin{array}{l}1.8 \\
1.0 \\
1.0 \\
0.8 \\
1.1 \\
2.2\end{array}$ & $\begin{array}{l}0.6 \\
0.8 \\
0.7\end{array}$ & $\begin{array}{c}0.2 \\
0.1 \\
\operatorname{tr} \\
\text { tr }\end{array}$ \\
\hline Carbonates & $\begin{array}{l}\text { Pleistocene } \\
\text { Pliocene } \\
\text { upper Miocene } \\
\text { middle Miocene } \\
\text { lower Miocene } \\
\text { Oligocene } \\
\text { Cretaceous }\end{array}$ & $\begin{array}{l}8.0 \\
1.8 \\
\text { tr } \\
\text { tr } \\
2.8 \\
3.0\end{array}$ & $\begin{array}{l}1.1 \\
1.0 \\
1.6\end{array}$ & $\begin{array}{l}0 \\
0 \\
0 \\
0\end{array}$ \\
\hline Smectite & $\begin{array}{l}\text { Pleistocene } \\
\text { Pliocene } \\
\text { upper Miocene } \\
\text { middle Miocene } \\
\text { lower Miocene } \\
\text { Oligocene } \\
\text { Cretaceous }\end{array}$ & $\begin{array}{l}41.0 \\
40.7 \\
35.4 \\
57.5 \\
55.0 \\
55.1\end{array}$ & $\begin{array}{l}40.8 \\
40.6 \\
42.9\end{array}$ & $\begin{array}{l}43.8 \\
44.4 \\
39.9 \\
44.5\end{array}$ \\
\hline
\end{tabular}

TABLE 11 - Continued

\begin{tabular}{llccc}
\hline Component & Stratigraphic Unit & Group A & Group B & Group C \\
\hline \multirow{2}{*}{ Illite } & Pleistocene & 35.8 & 38.0 & 40.9 \\
& Pliocene & 36.8 & 41.5 & 40.9 \\
& upper Miocene & 44.4 & 43.5 & 48.0 \\
& middle Miocene & 30.2 & & 46.6 \\
& lower Miocene & 32.2 & & \\
& Oligocene & 29.7 & & \\
& Cretaceous & & & 43.0 \\
Chlorite & Pleistocene & 15.8 & 15.5 & 11.3 \\
& Pliocene & 16.9 & 13.5 & 10.8 \\
& upper Miocene & 16.0 & 10.4 & 6.8 \\
& middle Miocene & 8.9 & & 3.1 \\
& lower Miocene & 11.0 & & \\
& Oligocene & 13.7 & & 2.4 \\
& Cretaceous & & & 3.9 \\
Kaolinite & Pleistocene & 7.4 & 5.7 & 4.2 \\
& Pliocene & 5.8 & 4.4 & 5.1 \\
& upper Miocene & 4.6 & 3.3 & 5.8 \\
& middle Miocene & 3.4 & & \\
& lower Miocene & 1.9 & & 7.4 \\
\hline Oligocene & 2.7 & & \\
& Cretaceous & & &
\end{tabular}

A

B

C AGE

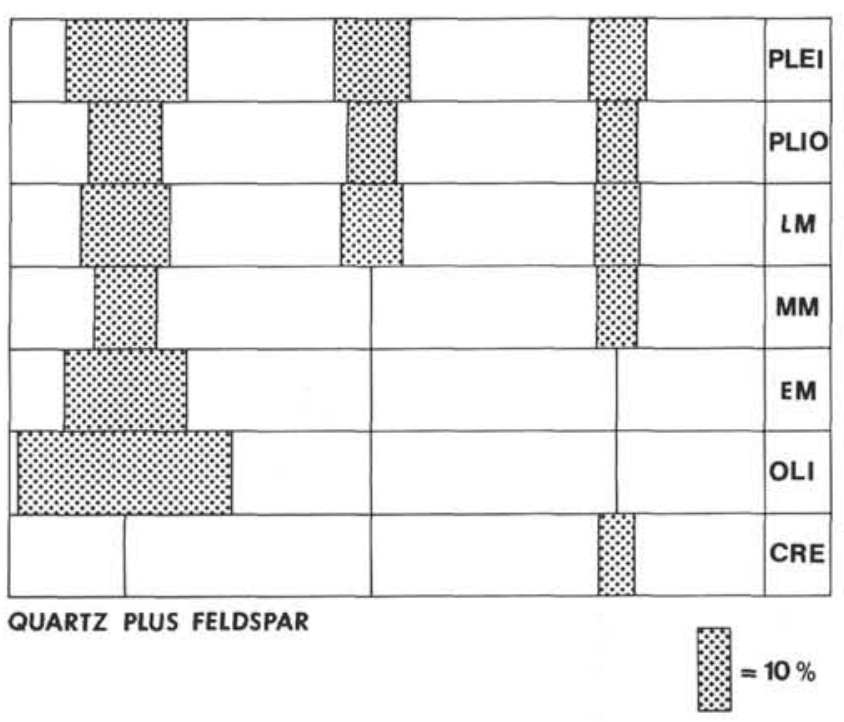

Figure 12. Average percentages of quartz plus feldspar in the different stratigraphic units. 
A B C AGE A B C

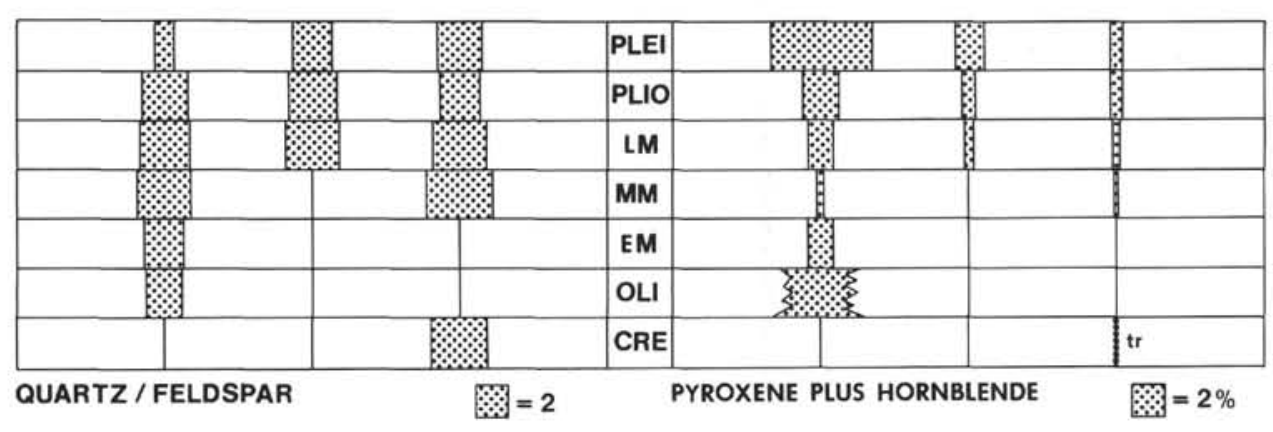

A B C AGE A B C

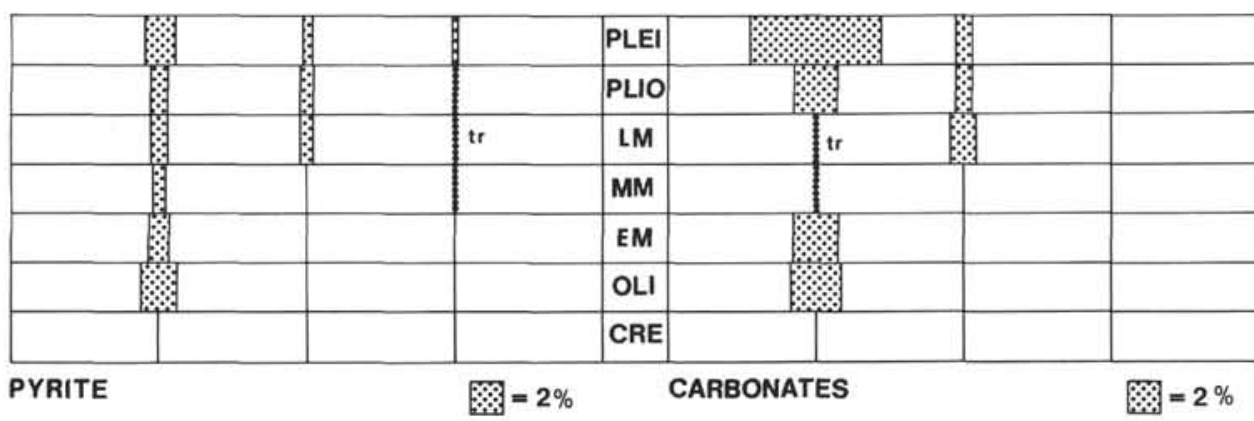

Figure 13. Quartz/feldspar ratio and average percentages of the minor constituents pyroxene plus hornblende, pyrite, and carbonates in the different stratigraphic units.

A

B $\quad$ C $\quad$ AGE



Figure 14. Average percentages of clay minerals plus volcanic glass in the different stratigraphic units. 
A B C AGE A B C

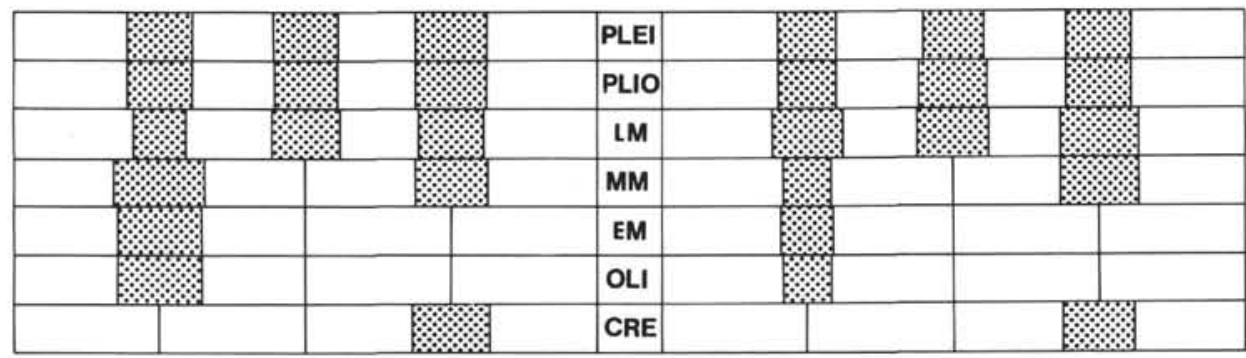

SMECTITE

: $=10 \%$ ILLITE

冬 $=10 \%$

A B C AGE A B C

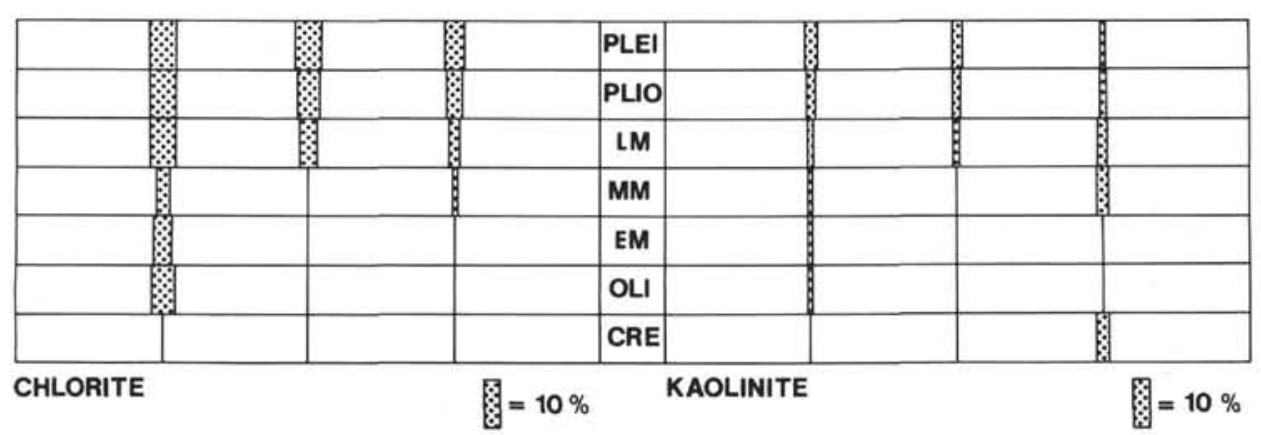

Figure 15. Average percentages of selective amounts of the different clay mineral groups smectite, illite, chlorite, and kaolinite in the different stratigraphic units.

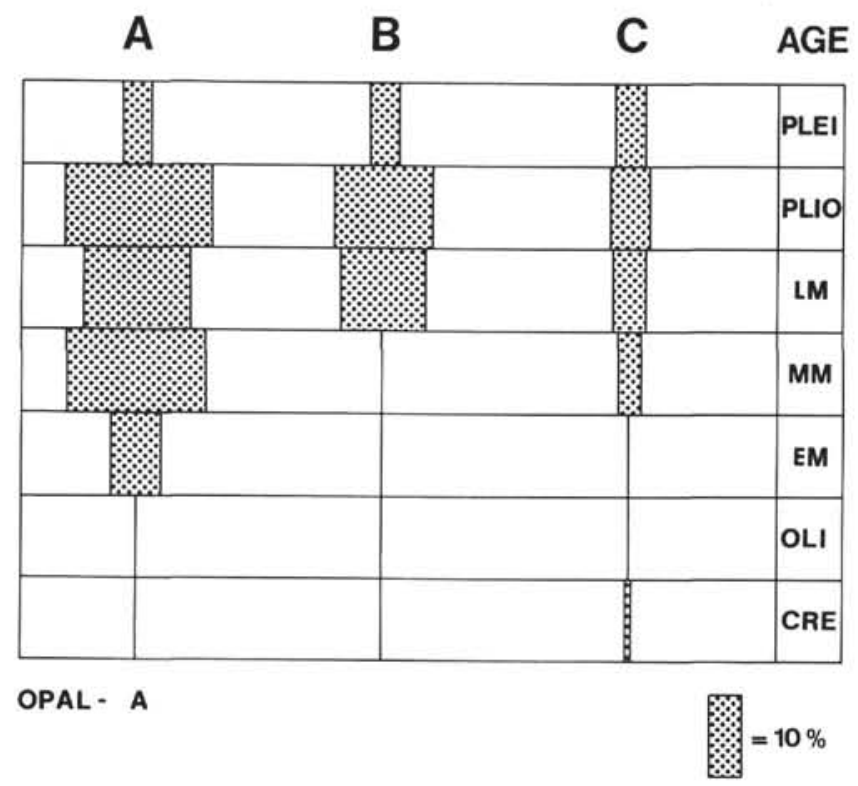

Figure 16. Average percentages of opal- $A$ in the different stratigraphic units. 


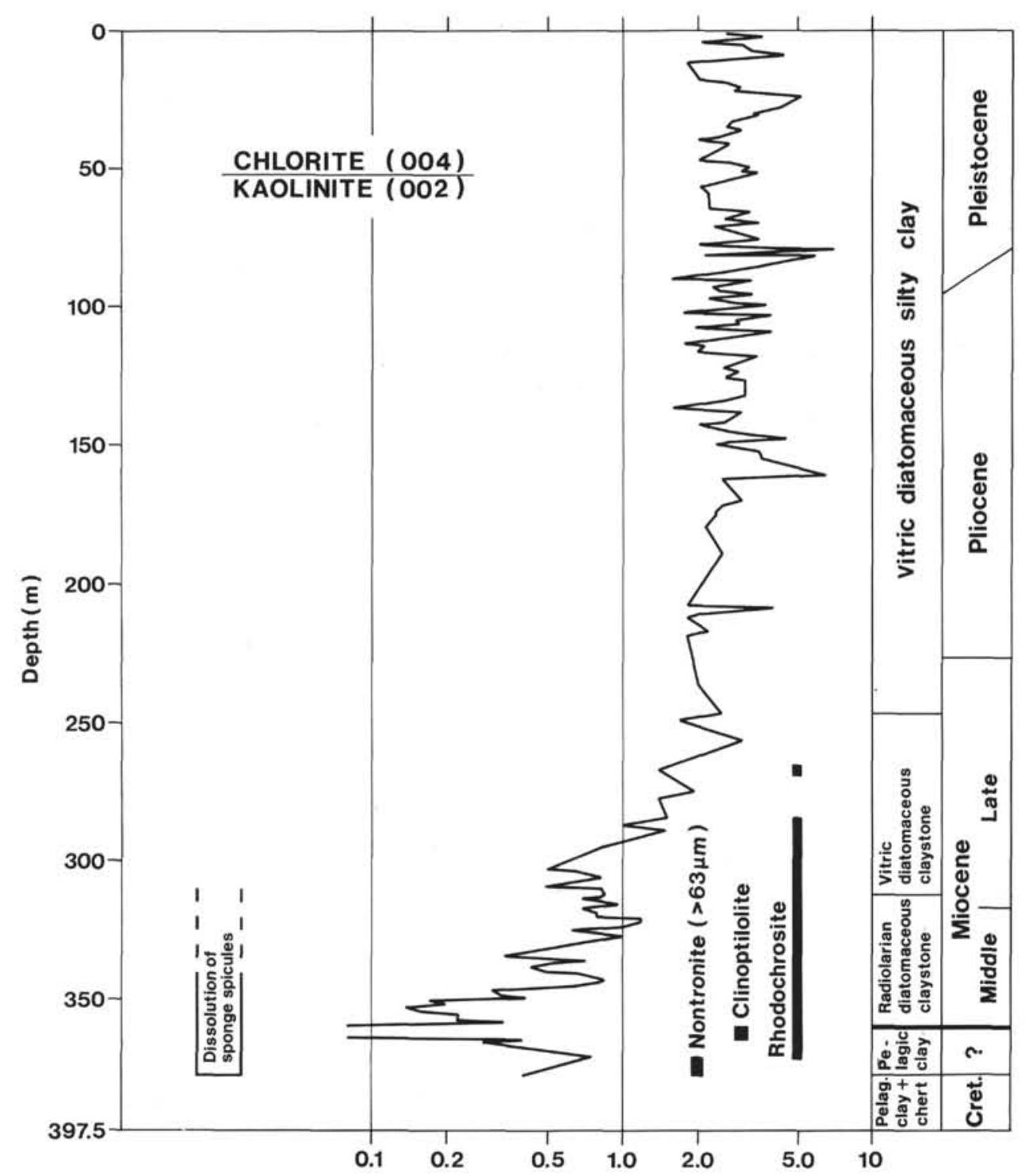

Figure 17. Chlorite/kaolinite ratio, Site 436. 




Figure 18. Chlorite/kaolinite ratio, Site 438. 


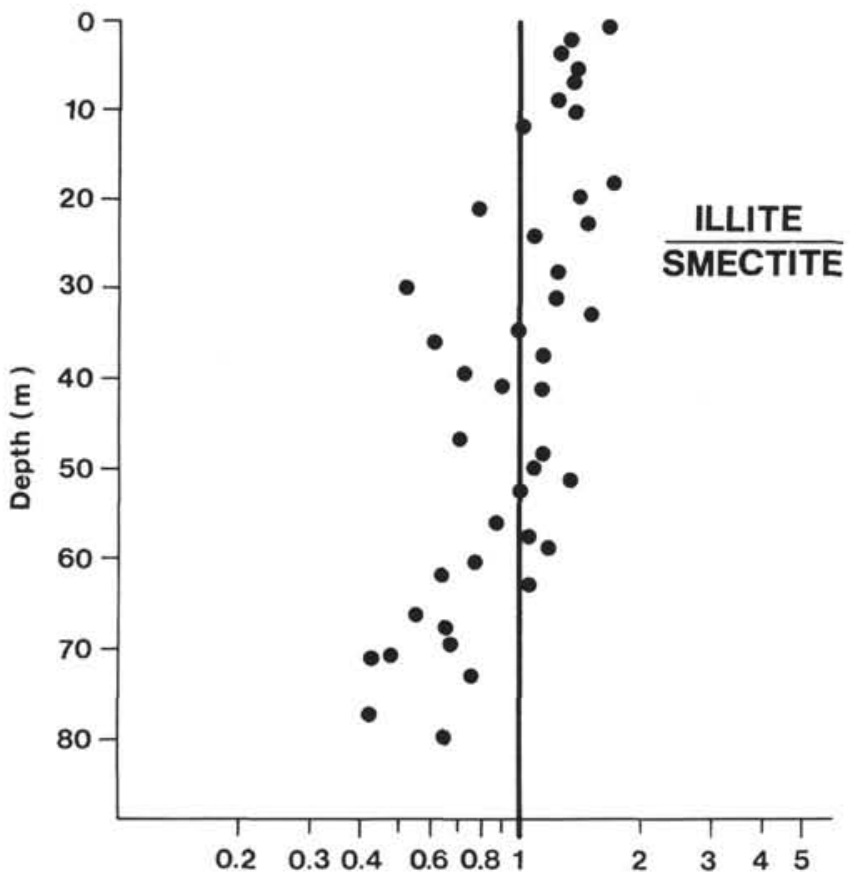

Figure 19. Illite/smectite ratio, Site 436, Pleistocene.



Figure 20. Sharpness of the (001) peak of glycolated smectite, Site 440. 

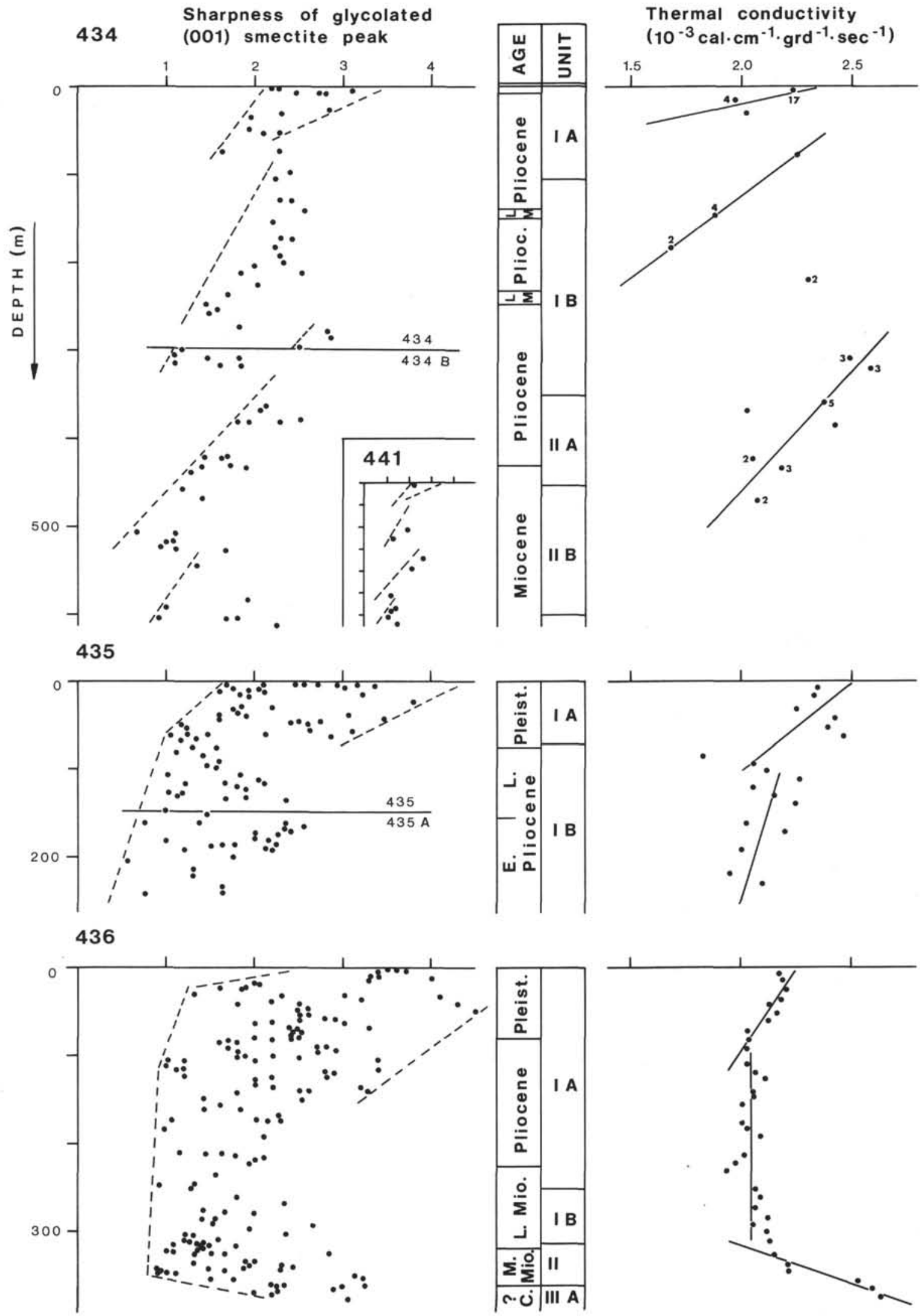

Figure 21. Correlation between sharpness of glycolated (001) smectite peak and thermal conductivity at Sites 434, 435, 436, and 441 . 




Figure 22. Stratigraphic comparison of the average percentages of pyroxene plus hornblende with the number of ash layers per million years. 
WEST

HONSHU IS

$\overbrace{\text { Kitakami }}^{\text {HONSHU IS }}$

CONTINENTAL

SHELF

Massif

HOLOCENE

SHEL SLOPE DEEPSEA TERRACE

JAPAN

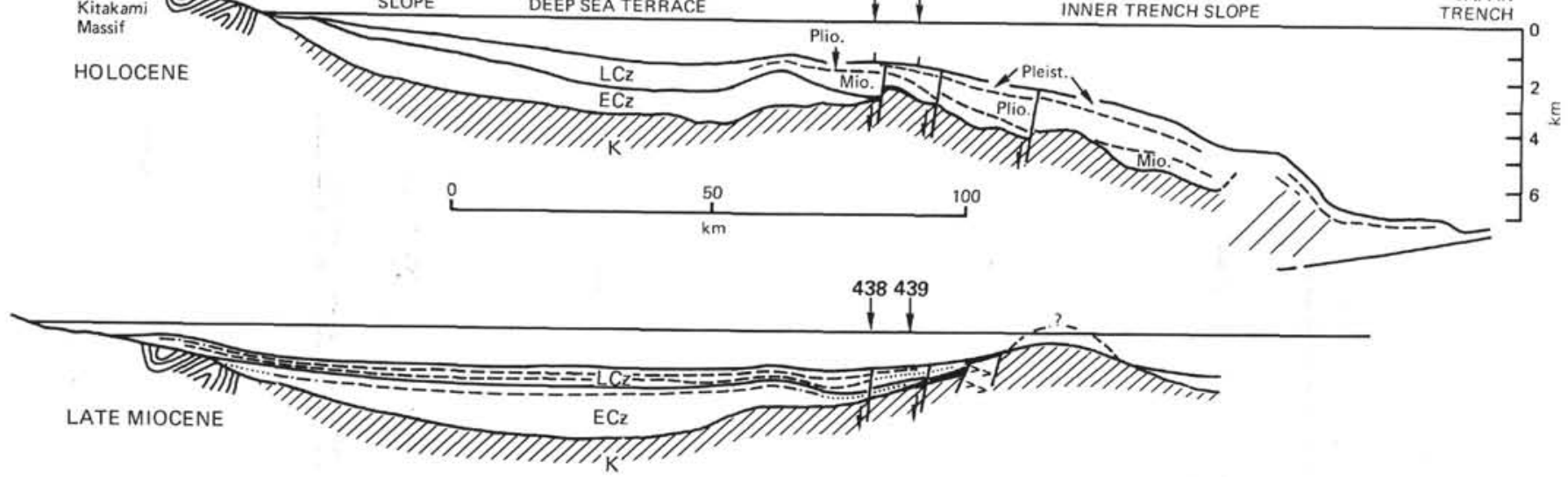

눈

$\frac{50}{\mathrm{~km}}$

100 TRENCH
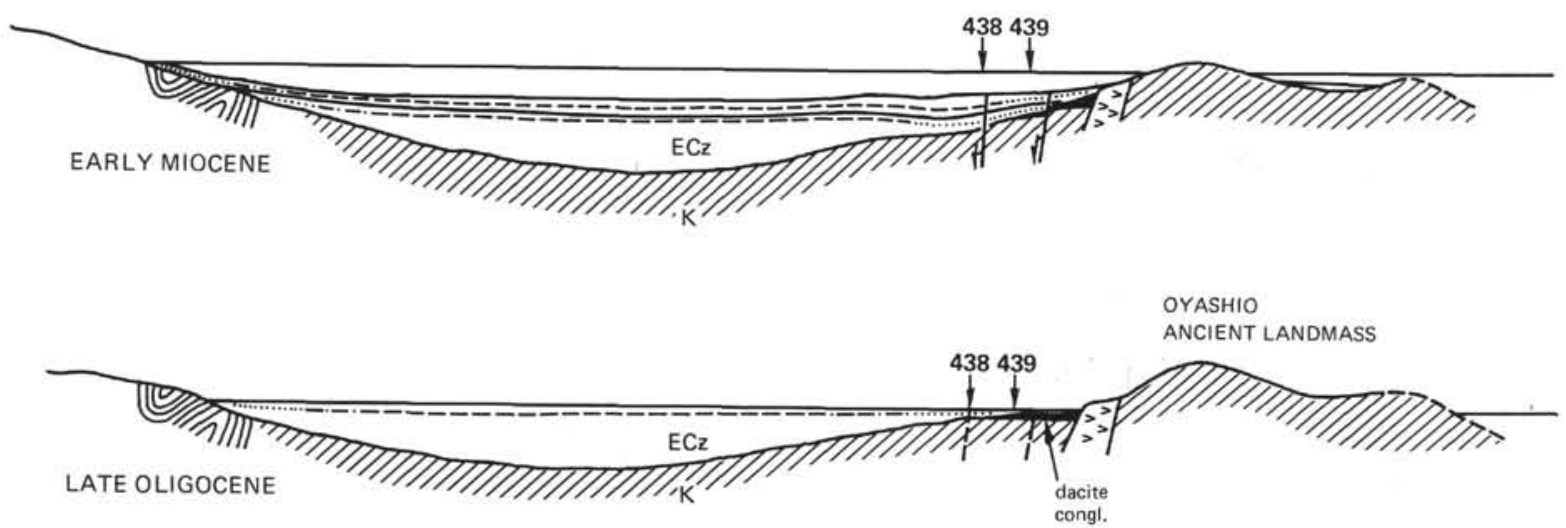

Figure 23. Diagrammatic history of subsidence of the Oyashio landmass on the basis of Leg 57 sampling and JNOC multichannel records (von Huene and Nasu, 1978).

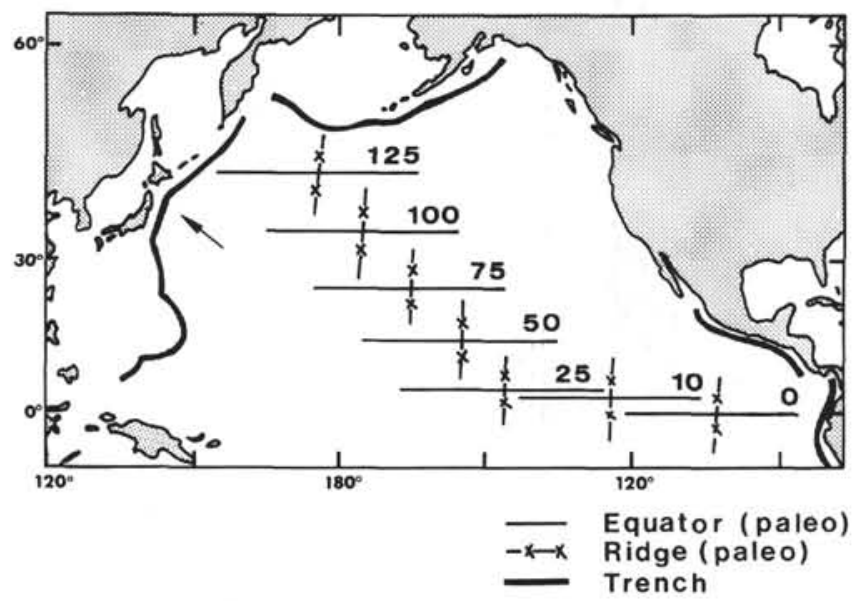

Figure 24. Age structure of the Pacific crust and drift of the position of Site 436 (after Heezen et al., 1973). 


\section{PLATE 1}

Figure 1 Rhodochrosite, "bow-tie" twin. Sample 436-37-4, $66 \mathrm{~cm}$.

Figure 2 Rhodochrosite, repeatedly twinned. Sample 436$35-1,58 \mathrm{~cm}$.

Figure 3 Pyrite, framboide plus octahedrons growing on the inner side of a diatom valve. Sample 436-11-2, $84 \mathrm{~cm}$.

Figure 4 Two cuprite crystals $\left(\mathrm{Cu}_{2} \mathrm{O}\right)$ on the surface of a radiolarian shell. Sample 436-31.

Figure 5 Nontronite spherule pseudomorph after glass. Sample 436-40-7, $14 \mathrm{~cm}$.

Figure 6 Detail of Fig. 5. Sample 436-40-7, $14 \mathrm{~cm}$. 
PLATE 1
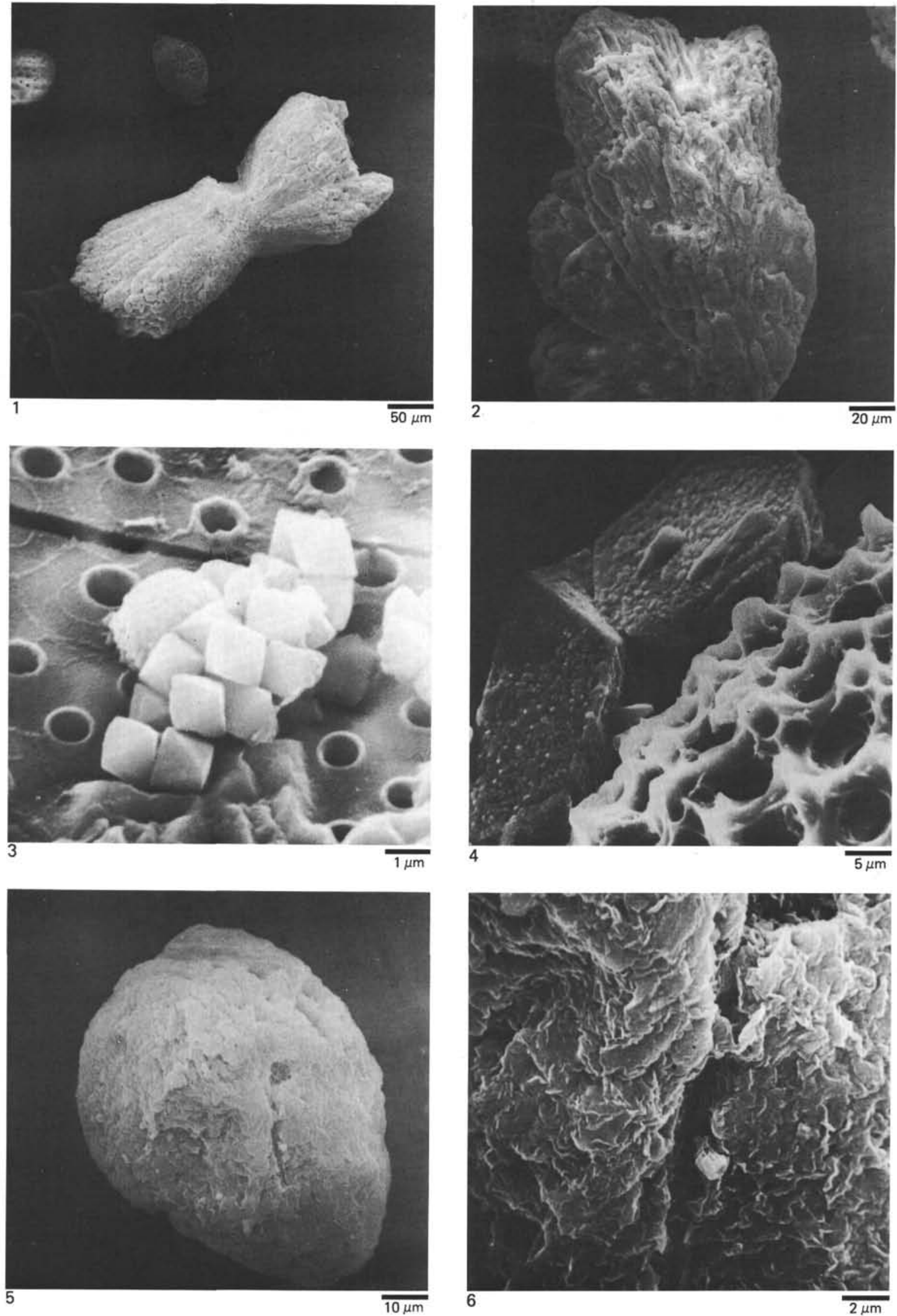